


\section{Pohjoismaat vihreässä murroksessa - enemmän kuin naapureita}

Strategisia suosituksia Pohjoismaiden vuoteen 2030 tähtäävään ympäristö- ja ilmastoyhteistyöhön

Tine Sundtoft

ANP 2018:750

ISBN 978-92-893-5545-2 (PDF)

ISBN 978-92-893-5546-9 (EPUB)

http://dx.doi.org/10.6027/ANP2018-750

(C) Pohjoismaiden ministerineuvosto 2018

Ulkoasu: Mette Agger Tang

Kannen valokuva: Scanpix.dk

\section{Pohjoismainen yhteistyö}

Pohjoismainen yhteistyö on yksi maailman laajimmista alveellisista yhteistyömuodoista. Yhteistyön piiriin kuuluvat Islanti, Norja, Ruotsi, Suomi ja Tanska sekä Ahvenanmaa, Färsaaret ja Grönlanti.

Pohjoismaista yhteistyötä tehdään politiikan, talouden ja kulttuurin aloilla tärkeänä osana eurooppalaista ja kansainvälistä yhteistyötä. Pohjoismaisen yhteisön tavoitteena on vahva Pohjola vahvassa Euroopassa.

Pohjoismainen yhteistyö pyrkii vahvistamaan pohjoismaisia ja alveellisia etuja ja arvoja globaalissa maailmassa. Maiden yhteiset arvot lujittavat osaltaan Pohjolan asemaa yhtenä maailman innovatiivisimmista ja kilpailukykyisimmistä alveista.

\section{Pohjoismaiden ministerineuvosto}

\section{Nordens Hus}

Ved Stranden 18

DK-1061 København K

www.norden.org

Pohjoismaisia julkaisuja voi ladata osoitteesta www.norden.org/nordpub 


\section{POHJOISMAAT VIHREÄSSÄ MURROKSESSA \\ - ENEMMÄN KUIN NAAPUREITA}

TINE SUNDTOFT

Strategisia suosituksia

Pohjoismaiden vuoteen 2030

tähtäävään ympäristö- ja

ilmastoyhteistyöhön

(1) Pohjoismaiden ministerineuvosto 


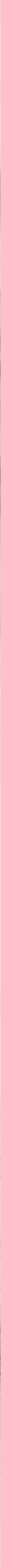




\section{SISÄLLYS}

7

ESIPUHE

9 JOHDANTO

12 PÄÄSUOSITUS: Edistetään vahvasti Pariisin ilmastosopimuksen ja Agenda 2030 -toimintaohjelman tavoitteiden täyttämistä Pohjoismaissa ja maailmanlaajuisesti

14 SUOSITUS 2: Laaditaan ja toteutetaan vähäpäästöiseen yhteiskuntaan tähtäävän pohjoismaisen yhteistyön työsuunnitelma

16 SUOSITUS 3: Perustetaan pohjoismainen foorumi edistämään muovin myrkytöntä kiertotaloutta

18 SUOSITUS 4: Edistetään tietoon pohjautuvaa haitallisten aineiden korvaamista EU:n kemikaalilainsäädännön kautta

20 SUOSITUS 5: Vahvistetaan ympäristömyötäiseen talouteen ja yhteiskuntarakenteisiin siirtymisen etujen tuntemusta

22 SUOSITUS 6: Edistetään yhteistyötä pohjoismaisten ympäristömyötäisten ratkaisujen viennin edistämiseksi

24 SUOSITUS 7: Tuetaan ja vahvistetaan pohjoismaista Joutsenympäristömerkkiä

26 SUOSITUS 8: Tuetaan maita julkisten varojen käytön optimoinnissa ympäristömyötäiseen talouteen ja yhteiskuntarakenteisiin siirtymisen edistämiseksi

28 SUOSITUS 9: Järjestetään pohjoismainen huippukokous vihreiden rahoitusmarkkinoiden kehittämisestä

30 SUOSITUS 10: Kehitetään kansainvälisillä foorumeilla tehtävää pohjoismaista yhteistyötä koskeva suunnitelma

32 SUOSITUS 11: Laaditaan pohjoismainen toimintasuunnitelma ekosysteemien ilmastokestävyydestä ja luonnon monimuotoisuudesta

34 SUOSITUS 12: Kehitetään pohjoismaista hyötyä lisäävän pohjoismaisen yhteistyön muotoja 


\section{ESIPUHE}

Vuonna 1950 maapallon väkiluku oli 2,5 miljardia. Vuonna 2050 samalla maapallolla elää noin 10 miljardia inmistä. Maapallon väestö siis nelinkertaistuu 100 vuodessa. YK on todennut jo kauan sitten, ettei se onnistu ilman suunnitelmaa.

Tämän vuoksi YK perusti vuonna 1983 ympäristön ja kehityksen maailmankomission (WCED), jota kutsutaan usein myös Brundtlandin komissioksi. Komission "Yhteinen tulevaisuutemme" -raportissa korostettiin ympäristön, talouden ja sosiaalisen kehityksen yhteyttä. Meidän tulee täyttää tämänhetkiset tarpeet heikentämättä tulevien sukupolvien mahdollisuuksia täyttää omat tarpeensa.

32 vuotta myöhemmin vuonna 2015 YK:n yleiskokous päätti kestävän kehityksen 17 tavoitteesta, ja Pariisin ilmastosopimus hyväksyttiin myöhemmin samana vuonna. Meidän tulee pyrkiä rajoittamaan lämpötilan nousu enintään 1,5 asteeseen, kaikkien maiden tulee tiukentaa tavoitteitaan joka viides vuosi ja lisäksi tulee perustaa tehokas raportointijärjestelmä. Kaikki nämä seikat ovat tärkeitä, jotta voimme saavuttaa ilmastoneutraaliutta koskevan pitkän aikavälin tavoitteen tämän vuosisadan toisella puoliskolla.

Meillä on jo työhön tarvittavat tiedot ja toimintakehykset. Pohjoismailla on nyt mahdollisuus osoittaa, että niillä on myös tahtoa toimia edelläkävijänä muutoksessa, joka tarvitaan taataksemme siedettävät elinolot vuonna 2050 maapallolla asuvalle 10 miljardille ihmiselle.
Pohjoismaiden ministerineuvoston toimeksiannosta olen vieraillut eri puolilla Pohjolaa vanhemman erityisasiantuntijan Satu Reijosen kanssa. Olemme kävelleet 170 kilometriä ja pyöräilleet 70 kilometriä 119 kokouksen välillä. Olemme tavanneet tutkijoita, yritysjohtajia, poliitikoita, ympäristöjärjestöjä, kuntien ja hyväntekeväisyysjärjestöjen edustajia sekä monia muita. Kaikissa kokouksissamme olemme keskustelleet siitä, onko Pohjoismailla kykyä ja tahtoa toimia tiennäyttäjänä maailman tarvitsemassa muutoksessa. Kyllä meillä on. Mitä siis vielä odotamme?

Mikäli Pohjola aikoo olla edelläkävijä, Pohjoismaiden johtajien on päästävä yhteisymmärrykseen työn suunnasta. Suositukseni viitoittavat Pohjoismaiden mahdollista työtä globaalisti, kansallisesti, alveellisesti ja paikallisesti. Meidän tulee kantaa kortemme kekoon, ja voimme edistää työtä myös Pohjoismaiden ulkopuolella.

Kiitos Pohjoismaiden ministerineuvostolle saamastani toimeksiannosta. Kiitos kaikille tapaamilleni henkilöille, jotka ovat antaneet tähän työhön aikaansa ja asiantuntemustaan. Lisäksi kiitän Satu Reijosta, joka oli hyvää seuraa matkoilla ja joka on toiminut tämän raportin kirjoittajana. Minä vastaan raportin sisällöstä. Uskon, että suositukset voivat toimia suunnannäyttäjinä tiellä, jota meidän on nyt kuljettava - ja jonka ensimmäisenä etappina on vuosi 2030 -, mutta katseemme on suunnattu vuoteen 2050.

\section{5. maaliskuuta 2018 \\ Tine Sundtoft}




\section{JOHDANTO}

Pohjoismaat ovat tehneet usean vuosikymmenen ajan ympäristön- ja luonnonsuojeluyhteistyötä niin Pohjoismaissa kuin kansainvälisesti. Virallista hallitusyhteistyötä tehdään Pohjoismaiden ympäristöja ilmastoasiain ministerineuvoston puitteissa. Marraskuussa 2016 ympäristöasiain ministerineuvosto päätti pyytää pääsihteeriä käynnistämään ulkopuolisen selvityksen pohjoismaisen ympäristöja ilmastoyhteistyön tulevista mahdollisuuksista. Selvitys on osa ministerineuvoston Nyt Norden -uudistustyötä.

Tässä raportissa esitellään työn pohjalta laadittuja suosituksia. Ne ovat selvityksen laatijan riippumattomia ehdotuksia pohjoismaisen ympäristö- ja ilmastoyhteistyön kehittämiseksi. Suosituksissa keskitytään erityisesti seuraavien 5-10 vuoden aikana tehtävään pohjoismaiseen ympäristö- ja ilmastoyhteistyöhön, mutta niiden aikanäkökulma on pidempi. Suositukset edistävät osaltaan YK:n kestävän kehityksen Agenda 2030 -toimintaohjelman ympäristö- ja ilmastotavoitteiden täyttämistä. Nyt tehtävien päätösten on lisäksi voitava viedä kehitystä eteenpäin kohti tämän vuosisadan toista puoliskoa, johon mennessä Pariisin ilmastosopimuksen pitkän aikavälin tavoitteet on saavutettava.

Vuonna 2017 aloitettu selvitystyö saatiin päätökseen alkuvuodesta 2018. Tänä aikana selvityksen laatija piti yhteensä 119 kokousta, joihin osallistui yli 200 eri alojen edustajaa Islannista, Norjasta, Ruotsista, Suomesta ja Tanskasta sekä Ahvenanmaalta, Färsaarilta ja Grönlannista. Selvityksen laatija tapasi myös YK:n ympäristöohjelman UNEPin sekä EU:n edustajia. Keskustelut ovat toimineet sekä inspiraation lähteenä suosituksia laadittaessa että niiden pohjana.
Yleisiä havaintoja pohjoismaisesta ympäristö- ja ilmastoyhteistyöstä

Ympäristö- ja ilmastoyhteistyöhön paneudutaan Pohjoismaissa merkittävästi, ja kansalliset ministeriöt ja viranomaiset ovat vahvasti sitoutuneita työhön. Pohjoismaisesta yhteistyöstä saadaan näkemyksiä, tietoa ja verkostoja, joita osallistujat arvostavat omien sanojensa mukaan suuresti. Pohjoismaat ovat tiiviisti sidoksissa toisiinsa maantieteellisesti, kulttuurisesti ja taloudellisesti, ja näin maat voivat oppia toisiltaan ja jakaa resurssejaan ja osaamistaan yhteistyön kautta.

Pohjoismainen ympäristö- ja ilmastoyhteistyö ei ole kovin tunnettua Pohjoismaiden ulkopuolella. Ulkopuoliset sidosryhmät painottavat kuitenkin, että Pohjoismaiden vaikutusmahdollisuudet korostuvat, kun maat toimivat hyvänä esimerkkinä ja ajavat yhdessä konkreettisia ympäristö- ja ilmastokysymyksiä kansainvälisillä areenoilla.

Pohjoismaisessa ympäristö- ja ilmastoyhteistyössä on keskitytty vahvasti tiedon tuottamiseen. Yhteistyön pohjalta onkin saatu arvokasta tietoa erilaisista ympäristöön ja ilmastoon liittyvistä ongelmista. Pohjoismaisen yhteistyön kautta tuotettu tieto edistää osaltaan politiikan eri alojen kehittämistä ja niitä koskevia keskusteluja jo varhaisessa vaiheessa. Ratkaisujen löytämiseen ja täytäntöönpanoon keskittyvää konkreettisempaa yhteistyötä ei priorisoida samassa määrin kuin tiedon tuottamista. Sektorin yksittäiset konkreettisiin ratkaisuihin tähdänneet hankkeet ovat kuitenkin todiste tämäntyyppisen työn potentiaalista.

Pohjoismaisen ympäristö- ja ilmastoyhteistyön parissa käsitellään erittäin tärkeitä aiheita. Yhteistyötä tehdään monilla eri aihealveilla aina kosteikkojen suojelusta kiertotalouden liiketoimintamal- 
leihin useiden erilaisten asiantuntijaympäristöjen hyödyksi. Toisaalta pohjoismainen yhteistyö on suhteellisen sirpaleista, eikä yhteistyötä tehdä selvien strategisten yleistavoitteiden ja priorisointien puitteissa. Valittujen panostusalueiden selkeämpi priorisointi voisi parantaa työn näkyvyyttä ja tehoa. Yhteistyön tulevana haasteena on siis, miten strategista johtajuutta voidaan lisätä menettämättä sitä kiinnostusta ja sitoutumista, joka kumpuaa nykyisen yhteistyön monista teemoista ja laajasta asiantuntijaverkostosta.

\section{Raportin rakenne ja suositukset}

Raportti sisältää 12 pohjoismaista ympäristö- ja ilmastoyhteistyötä koskevaa suositusta. Niiden tavoitteena on esitellä mahdollisuuksia tehdä yhteistyöstä entistä ajankohtaisempaa ja konkreettisempaa vihreään talouteen ja ympäristömyötäisempiin yhteiskuntarakenteisiin siirtymisen vauhdittamiseksi. Tehtävä on mittava. Pohjoismaiden yhteiskuntien tulee saavuttaa ilmastoneutraalius samalla kun resurssien käyttöä ja kemikaaleihin liittyvät haitat minimioidaan. Yhteiskuntamme pohjana toimivien tuotanto- ja kulutusjärjestelmien on muututtava ratkaisevalla tavalla. Siirtyminen vähäpäästöiseen yhteiskuntaan on käynnistettävä toden teolla, jotta Pohjola voi osaltaan edistää Pariisin ilmastosopimuksen pitkän aikavälin tavoitteita. Ilmastonmuutos, luonnon monimuotoisuuden häviäminen ja arjen haitalliset kemikaalit ovat jo nyt konkreettisia haasteita.

Selvityksen 12 suositusta jakautuvat viiteen pääteemaan, joihin pohjoismaisen ympäristö- ja ilmastoyhteistyön tulee selkeästi panostaa. Mahdollisimman suuren vaikutuksen saamiseksi pohjoismaisen ympäristö- ja ilmastoyhteistyön tulee edistää:

1. konkreettisia ratkaisuja vihreään talouteen ja ympäristömyötäisiin yhteiskuntarakenteisiin siirtymiseksi

2. avaintoimijoiden mobilisointia

3. vihreään talouteen ja ympäristömyötäisiin yhteiskuntarakenteisiin siirtymisen rahoittamista

4. pohjoismaisen äänen vahvistamista Pohjoismaiden ulkopuolella

5. sopeutumista ilmastonmutokseen.
Ensimmäinen suositus, pääsuositus, kuvaa toiminnan laajempia puitteita, joihin pohjoismaisen ympäristö- ja ilmastoyhteistyön tulee vaikuttaa vahvasti. Pohjoismaisen ympäristö- ja ilmastoyhteistyön perustavana lähtökohtana tulee olla kunnianhimoinen pyrkimys täyttää Pariisin ilmastosopimuksen sekä ympäristöä ja ilmastoa koskevat kestävän kehityksen tavoitteet.

Konkreettisia ratkaisuja vihreään talouteen ja ympäristömyötäisiin yhteiskuntarakenteisiin siirtymiseksi. Suositukset 2-4 sisältävät kolme toimenpiteitä ja panostusalueita koskevaa ehdotusta konkreettisten toimien ja ratkaisujen kehittämiseksi. Ensimmäisessä suosituksessa ehdotetaan, että pohjoismaisessa yhteistyössä otetaan käyttöön strateginen lähestymistapa vähäpäästöiseen yhteiskuntaan tähtäävässä työssä. Pohjoismaisen yhteistyön puitteissa tulee laatia pitkän aikavälin temaattinen työsuunnitelma vähäpäästöisistä yhteiskunnista. Työsuunnitelman pohjalta tulee käynnistää konkreettisia toimenpiteitä ja toimia valituilla panostusalueilla. Suosituksessa 3 nostetaan esiin kiertotalous keskeisenä yhteistyöalana ja ehdotetaan kiertotalouteen ja muoviin liittyvää erityistä kärkihanketta. Työ pohjautuu käynnissä olevaan pohjoismaiseen työhön ja seuraa EU:n puitteissa tapahtuvaa kehitystä. Muovialalta saatuja kokemuksia voidaan soveltaa muihin materiaalivirtoihin, joissa tulee soveltaa kiertotaloutta. Suosituksessa 4 ehdotetaan että haitallisten kemikaalien korvaamiseen tähtäävästä pitkän aikavälin työstä tehdään priorisoitu painopistealve. Haitallisten kemikaalien korvaaminen järjestelmällisesti ja riskittömästi tulevaisuudessa edellyttää EU:n kemikaalilainsäädännön kehittämistä ja täytäntöönpanoa. Sen vuoksi suositellaan pohjoismaisen työn jatkamista ja lisäämistä alalla.

Avaintoimijoiden mobilisointi. Vähäpäästöisten ratkaisujen ja järjestelmämuutosten täytäntöönpanoa koskevat päätökset tehdään useimmiten ympäristö- ja ilmastosektorin ulkopuolella. On tärkeää, että kaikki asianomaiset toimijat osallistuvat työhön ja toimivat muutoksista saatavaa etua koskevan ajankohtaisen tiedon pohjalta. Suosituksessa 5 pohjoismaista ympäristö- ja ilmastosektoria kehotetaan mahdollistamaan ja helpottamaan 
työtä jakamalla tietoa vihreään talouteen ja ympäristömyötäisiin yhteiskuntarakenteisiin siirtymisen taloudellisista ja sosiaalisista eduista. Suosituksessa 6 ehdotetaan, että ympäristö- ja ilmastosektori edistää pohjoismaisten ympäristömyötäisten ratkaisujen vientiyhteistyötä. Suosituksessa 7 priorisoidaan panostusta Joutsen-ympäristömerkkiin sektorin suoraan kuluttajiin kohdistuvassa työssä.

Vihreään talouteen ja ympäristömyötäisiin yhteiskuntarakenteisiin siirtymisen rahoittaminen.

Perustavanlaatuinen panostus puhtaampiin ja ilmastoneutraalimpiin tuotanto- ja kulutusjärjestelmiin siirtymiseksi edellyttää suuria investointeja vihreään teknologiaan, infrastruktuuriin ja hallinnollisiin innovaatioihin. Siinä tarvitaan merkittävää julkista ja yksityistä pääomaa. Suosituksessa 8 ehdotetaan pohjoismaista kokemustenvaihtoa ympäristöinnovaatioita koskevista julkisista tukimekanismeista, ympäristömyötäisistä julkisista hankinnoista ja julkisista ympäristöasiat huomioon ottavista infrastruktuuri-investoinneista. Suosituksessa 9 painotetaan tarvetta käynnistää korkean tason poliittisia neuvotteluja vihreiden rahoitusmarkkinoiden kehittämisestä.

Pohjoismaisen äänen vahvistaminen Pohjoismaiden ulkopuolella. Suositus 10 koskee mahdollisuutta vahvistaa pohjoismaista vaikuttamista tärkeimmissä kansainvälisissä neuvotteluissa tehokkaan suunnittelun avulla.

Sopeutuminen ilmastonmuutokseen. Lämpötilan nousu ja merenpinnan kohoaminen lisäävät painetta, joka kohdistuu usein jo entuudestaan heikentyneisiin ekosysteemeihin ja luonnon monimuotoisuuteen. Samalla vaarana on, että elintarviketuotannon perusedellytykset sekä puhtaan veden ja ilman saatavuus heikkenevät. Suosituksessa 11 painotetaan alveen ekosysteemien muutoskestävyyttä koskevaa yhteistyötä ja sen merkitystä ilmastonmuutokseen sopeutumiselle alveella.

Raportin viimeisessä suosituksessa käsitellään työn organisointia pohjoismaisen ympäristö- ja ilmastoyhteistyön tehokkuuden ja osallistavuuden edistämiseksi. 


\section{PÄÄSUOSITUS}

EDISTETÄÄN VAHVASTI PARIISIN ILMASTOSOPIMUKSEN JA AGENDA 2030 -TOIMINTAOHJELMAN TAVOITTEIDEN TÄYTTÄMISTÄ POHJOISMAISSA JA MAAILMANLAAJUISESTI

Maailman maat ovat yhdistäneet voimansa Pariisin ilmastosopimuksen ja Agenda 2030 -ohjelman parissa. Pohjoismaista ympäristö- ja ilmastoyhteistyötä tulee käyttää strategisena työkaluna näiden sopimusten edistämisessä ja täytäntöönpanossa niin kansallisesti kuin kansainvälisestikin.

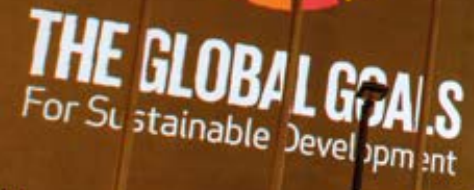


Maailman maat eivät ole koskaan aiemmin olleet yhtä yksimielisiä suurimmista ympäristö- ja ilmastohaasteista. YK:n jäsenvaltiot ovat hyväksyneet 17 universaalia kestävän kehityksen tavoitetta. Pariisin ilmastosopimus antaa suuntaa maiden työlle ilmastonmuutoksen rajoittamiseksi. Maiden yhteisymmärrys ja halu ratkaista maailman kiireellisimmät ympäristöongelmat on syntynyt tilanteessa, jossa luonnon sietokyky on suuren uhan alla.

YK:n entinen ilmastoasioiden johtaja Christiana Figueres, hallitustenvälisen ilmastonmuutospaneelin (IPCC) edustaja Hans Joachim Schellnhuber sekä muut asiantuntijat painottavat kirjoittamassaan artikkelissa, että voimme vielä välttyä peruuttamattomilta ilmastonmuutoksilta, mikäli onnistumme vähentämän ilmastopäästöjä tarpeeksi vuoteen 2020 mennessä. Aika on kuitenkin käymässä vähiin, jotta voisimme saada maailman lämpötilan nousun rajoitettua kahteen asteeseen Pariisin ilmastosopimuksen mukaisesti. Mitä kavemmin odotamme, sitä vaikeampaa ja kalliimpaa ilmaston ja luonnon muutosten torjuminen on. Sen seurauksena suuri osa maiden tekemästä työstä muiden ympäristöhaasteiden, kuten luonnon monimuotoisuuden heikentymisen parissa voi mennä hukkaan. Pariisin ilmastosopimuksen kehittämisen ja täytäntöönpanon tulee sen vuoksi olla pohjoismaisen ympäristö- ja ilmastoyhteistyön tärkein painopistealue lähitulevaisuudessa.

Riippumatta siitä, kuinka paljon onnistumme vähentämään hiilidioksidipäästöjä, ilmastonmuutos on jo täyttä totta. Tämä koskee koko Pohjolaa ja etenkin arktista aluetta, jossa lämpötilan jatkuva nousu on erityisen selvästi havaittavissa. Tästä johtuen meidän on pyrittävä vähentämään uusien sääolojen seurauksia muun muassa luonnon monimuotoisuudelle. Ilmastotyöhön sisältyvät siis myös toimet ilmastonmuutokseen sopeutumiseksi.

Asiantuntijat varoittavat myös luonnon monimuotoisuuden entistä suuremmasta köyhtymisestä ihmisten toiminnan seurauksena. Luonnon monimuotoisuuden kato onkin yksi Pohjoismaiden luonnon suurimmista nykyisistä haasteista. Tulevina vuosina nähdään, voimmeko jarruttaa alveen luonnon monimuotoisuuden köyhtymistä niin maalla kuin vesialueillakin. Sen säilyttäminen ja suojelu takaavat, että saamme luonnosta ruokaa, vettä, ilmaa, materiaaleja ja lääkkeitä tulevaisuudessakin. Lisäksi monimuotoisuus on tärkeässä asemassa ekosysteemiemme kestävyyden ja vastustuskyvyn säilyttämisessä ilmastonmuutoksen aiheuttamien haasteiden edessä.

Kolmas suuri ympäristöhaaste on ihmisten ja luonnon entistä suurempi altistuminen tuotteista ja tuotantoprosesseista lähtöisin oleville haitallisille kemikaaleille. Selvityksissä on todettu, että ihmisen veressä ja kehon kudoksissa on entistä enemmän haitallisia kemikaalijäämiä, mukaan lukien torjunta-aineita, kasvinsuojeluaineita, raskasmetalleja, pehmittimiä ja palonestoaineita. Haitalliset kemikaalit leviävät kaikkialle: muvalla maailmassa tuotettuja ja käytettyjä kemikaaleja on havaittu esimerkiksi haavoittuvalla arktisella alveella. Emme vielä tunne hormonitoimintaa häiritsevien, neurotoksisten tai muuten haitallisten kemikaalien kaikkia yhteiskuntataloudellisia ja terveydellisiä seurauksia ihmisille, ympäristölle ja luonnolle.

Pariisin ilmastosopimus ja kestävän kehityksen tavoitteet on laadittu ilmastossa ja luonnossa havaittujen negatiivisten muutosten pohjalta. Näiden kahden sopimuksen perimmäinen viesti ei kuitenkaan ole viesti huolesta vaan tahdosta muuttua. Sopimusten myötä maailma on päässyt yksimielisyyteen muutoksesta.

On tärkeää, että maailman maat osallistuvat Pariisin ilmastosopimuksen ja Agenda 2030:n täytäntöönpanoon jatkossakin. Pohjoismaisen ympäristöyhteistyön lähtökohtana tulee olla tarvitun muutoksen ajaminen omalla alveellamme, mutta myös sen tukeminen muilla alueilla. Meidän tulee hyödyntää Pariisin ilmastosopimusta ja kestävän kehityksen tavoitteita muuttaaksemme kulutus- ja tuotantomallejamme, jotka nykyään edistävät ilmastonmuutosta, kestämätöntä materiaalinkäyttöä, monimuotoisuuden häviämistä ja elinympäristömme kemikalisoitumista. Pohjoismaisen ympäristö- ja ilmastoyhteistyön päätavoitteena tulee olla edistää voimakkaasti Pariisin ilmastosopimuksen ja Agenda 2030 -toimintaohjelman tavoitteiden saavuttamista Pohjoismaissa ja maailmanlaajuisesti. 


\section{SUOSITUS 2}

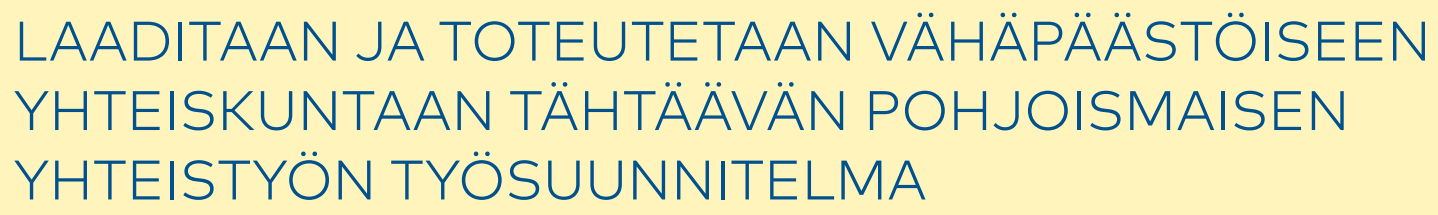

Pohjoismaat ovat sitoutuneet ilmastopäästöjen vähentämiseen sekä EU:ssa että YK:ssa. Lisäksi kaikkien Pohjoismaiden tavoitteena on ilmastoneutraalius. Pohjoismaisen ympäristö- ja ilmastosektorin tulee suhtautua ilmastoneutraaliuteen tähtäävään työhön järjestelmällisemmin ja laatia vähäpäästöiseen yhteiskuntaan tähtäävä pohjoismaisen yhteistyön temaattinen työsuunnitelma.

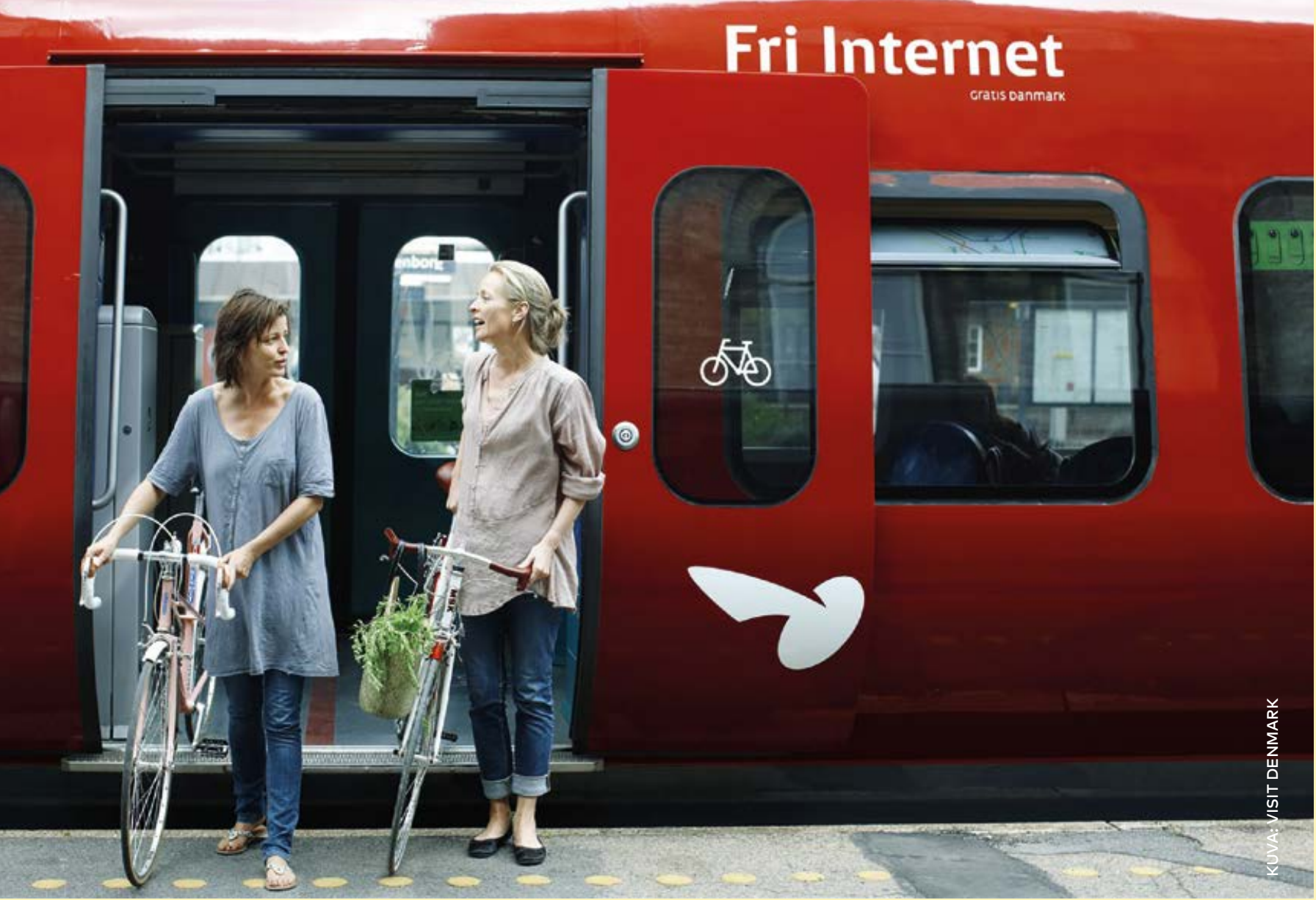


Pohjoismaat pyrkivät täyttämään EU:n vuoteen 2030 ulottuvat ilmastotavoitteet ja tämän vuosisadan toiseen puoliskoon tähtäävät tavoitteet Pariisin ilmastosopimuksen lisäksi. Huomattavia hilioksidipäästövähennyksiä tarvitaan edelleen kaikissa Pohjoismaissa ja etenkin aloilla, jotka eivät ole vielä onnistuneet vakauttamaan ilmastopäästöjään. On vielä pitkä matka siihen, että Pohjolaa voidaan kutsua ilmastoneutraaliksi alueeksi, etenkin jos mukaan lasketaan myös kulutukseemme liittyvät päästöt Pohjoismaiden ulkopuolelta.

Tässä välttämättömässä muutoksessa Pohjoismaat voivat ja niiden tulee toimia yhdessä. Monet maiden kohtaamat haasteet ovat samanlaiset maasta toiseen. Globaalista näkökulmasta myös elämäntapamme, kaupunkimme, asumismuotomme ja liikennejärjestelmämme ovat samankaltaisia. Pohjoismailla on myös toisiaan täydentäviä teknologisia ja suunnitelmallisia ratkaisuja ja tietoa joiden avulla voidaan päästä lähemmäksi tavoitetta. Pohjoismaat muodostavat lisäksi maailman 11. suurimman talouden, jolla on paljon vihreää ostovoimaa ja sen myötä paljon muutoksessa tarvittavia resursseja.

Ilmastotavoitteiden saavuttamiseksi meidän tulee panostaa konkreettisia tuloksia antavaan työhön. Pohjoismaisessa ilmastoyhteistyössä tulee sen vuoksi keskittyä vähäpäästöiseen yhteiskuntaan tähtääviin konkreettisiin toimiin. Meidän tulee panna täytäntöön lupaavia ilmastoinnovaatioita, jotka ovat jo osoittaneet tehonsa. Lisäksi meidän tulee vauhdittaa energia-, rakennus-, elintarvike- ja liikennealan järjestelmämuutoksia. Näiden alojen ratkaisut ovat myös kilpailukykyisen alueen ja vahvan elinkeinoelämän avaimia tulevaisuuden ilmastoneutraaliin maailmaan.

Konkreettisena suosituksena on, että pohjoismaisella ympäristö- ja ilmastosektorilla laaditaan ja pannaan täytäntöön työsuunnitelma, joka koskee pohjoismaista yhteistyötä vähäpäästöisen yhteiskunnan saavuttamiseksi vuoteen 2050 mennessä. Työsuunnitelman tulee edistää ilmastojohtajuutta, kokemustenvaihtoa, vuoropuhelua ja syvempää pohjoismaista yhteistyötä strategisilla aloilla. Tavoitteena on tuoda pohjoismainen yhteistyö lähemmäksi konkreettisia valintoja ja päätöksiä, joita kukin maa tule tekemään ja toteuttamaan ilmastoneutraaliuden saavuttamiseksi. Työsuunnitelman pääelementit ovat seuraavat:

1. aikataulutetut neuvottelut ilmastoneutraaliuden avainaiheista, kuten vähäpäästöisestä liikkuvuudesta, rakentamisesta ja asumisesta, ilmastoneutraaleista kaupungeista ja pienyhdyskunnista, elintarvikkeista, energiasta, kompromisseista ilmaston ja luonnon monimuotoisuuden välillä sekä ilmastolainsäädännön kehittämisestä

2. pohjoismainen kokemustenvaihto osana neuvotteluja avainaiheista, esimerkiksi kustannustehokkaista toimenpiteistä, mahdollisesti negatiivisia ilmastovaikutuksia aiheuttavista politiikan välineistä sekä ympäristöinnovaatioiden käyttöönoton rahoitusmenetelmistä

3. aiheiden parissa tehtävän pohjoismaisen yhteistyön konkretisointi, esimerkiksi koordinoitu tiedontuotanto politiikan prosessien tai kansainvälisten neuvottelujen tarpeisiin, yhteiset pelisäännöt tai sääntöjen yhdenmukaistaminen, Pohjoismaiden välinen työnjako ja yhteistyö elinkeinoelämän kanssa.

Neuvotteluiden tueksi laaditaan tausta-aineistoa jokaisesta avainaiheesta.

Aiheita käsitellään pohjoismaisella tasolla, mielellään ministerien kesken. Koska vähäpäästöisen yhteiskunnan perustamista koskevista päätöksistä ja ratkaisuista vastaavat usein muut kuin ympäristö- ja ilmastosektorin toimijat, neuvotteluja tulee käydä vuoropuhelussa muiden alojen ministerien ja asianomaisten toimijoiden kanssa. Liikenne-, energia-, rakennus- ja kaupunkikehitysalan toimijat ovat esimerkiksi avainasemassa Pariisin ilmastosopimuksen täytäntöönpanossa. Tässä ympäristö- ja ilmastosektori voi osoittaa johtajuutta toimimalla aloitteentekijänä ja edistäjänä, koska sillä on laaja tietopohja ja tuntemus ilmasto- ja ympäristövaikutuksista sekä ympäristömyötäiseen talouteen ja yhteiskuntarakenteisiin siirtymisen instrumenteista ja ratkaisuista. 


\section{SUOSITUS 3}

\section{PERUSTETAAN POHJOISMAINEN FOORUMI EDISTÄMÄÄN MUOVIN MYRKYTÖNTÄ KIERTOTALOUTTA}

Jotta muovin käytöstä luonnolle, vesiympäristöille ja ilmastolle aiheutuvia kielteisiä vaikutuksia voidaan vähentää, tulee Pohjoismaiden työskennellä järjestelmällisesti vauhdittaakseen muovien kiertotaloutta. Tämä perustuu pitkäikäisiin tuotteisiin, uvdelleenkäyttöön, myrkyttömään kiertokulkuun sekä käytetyn muovin toimiviin markkinoihin. Muovien kiertotalouden tueksi tulee perustaa pohjoismainen foorumi vuoropuhelun, kokemustenvaihdon ja kansallisten toimien koordinoinnin edistämiseksi. Foorumi voi myös käynnistää pohjoismaisia hankkeita aiheeseen liittyen.

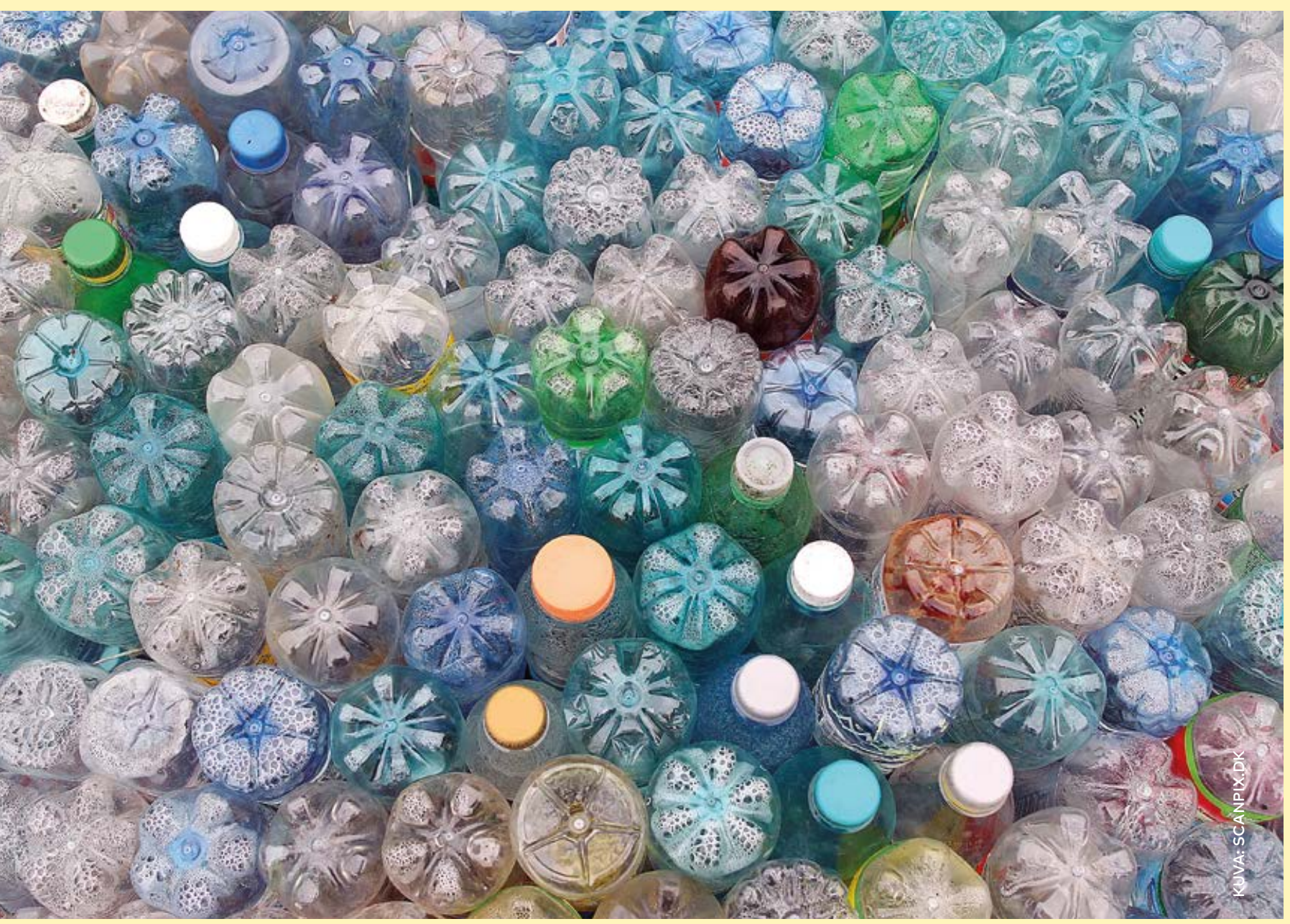


Pohjoismaiden talouden tulee tulevaisuudessa perustua siihen, että materiaalit säilyvät kierrossa mahdollisimman pitkään. Tämä koskee perimmiltään kaikkea tuotantoa ja kulutusta, mutta työn alkuvaiheessa tietyt materiaalit ovat toisia tärkeämmällä sijalla. Muovi on yksi materiaaleista, jonka parissa tehtävää työtä tulee priorisoida. Muovinkäyttö on suurta ja kasvaa jatkuvasti niin Pohjoismaissa kuin muvallakin maailmassa. Siihen liittyvät ympäristö- ja ilmasto-ongelmat ovat edenneet niin pitkälle, ettei meillä ole muuta vaihtoehtoa kuin muuttaa muovinkäytön logiikkaa ratkaisevasti kohti kiertotaloutta.

Pohjoismaissa muovi on ollut asialistalla jo vuosia, viimeisimpänä meneillään olevassa ohjelmassa Nordic programme to reduce the environmental impact of plastic 2017-18. Pohjoismaat tekevät myös aktiivista kansallista työtä muoveihin liittyvissä kysymyksissä ja ympäristöasioissa. Vielä on kuitenkin paljon tehtävää ennen kuin Pohjoismaiden muovituotantoa ja -käyttöä voidaan kutsua kestäväksi: Pohjoismaissa poltetaan tai viedään kaatopaikoille 700000 tonnia muovia vuosittain. Samaan aikaan muovin uudelleenkäytön aste on suhteellisen alhainen muihin materiaaleihin verrattuna. Kaikissa Pohjoismaissa muovin kierrätyksessä ja uudelleenkäytössä on paljon hyödyntämätöntä potentiaalia.

Aiemmin tehdyn työn perusteella muovin kiertotalouden suurimmista esteistä ollaan laajalti yksimielisiä. Siitä huolimatta emme vieläkään ymmärrä täsmälleen, kuinka nämä ongelmat voitaisiin ratkaista käytännössä. Ratkaisua kaipaavia ongelmia ovat pitkään käyttöikään ja uudelleenkäyttöön tähtäävän suunnittelun puute, materiaaleihin ja lisäaineisiin, mukaan lukien haitallisiin kemikaaleihin, liittyvä puutteellinen tiedonkulku, riittämätön keräys- ja lajittelukapasiteetti sekä sekundäärisen muoviraaka-aineen hinta.

Pohjoismaiden tulee pyrkiä yhdessä löytämään ratkaisuja yllä mainittuihin ongelmiin. Kaikki Pohjoismaat ovat jo päässeet hyvin käyntiin kansal- lisen muovityönsä parissa. Sen vuoksi yhteistyön yhtenä tärkeimpänä tavoitteena tulee olla maiden välisen koordinoinnin lisääminen niin kansallisen tiedontuotannon kuin konkreettisia toimia koskevan kokemustenvaihdon parissa. Tämän perusteella suositellaan, että pohjoismaisen ympäristö- ja ilmastoyhteistyön puitteissa perustetaan vuoropuhelu- ja koordinointifoorumi, jossa käsitellään maiden toimia ja pohjoismaista yhteistyötä muovin myrkyttömän kiertotalouden edistämiseksi. Koordinoinnin ja kokemustenvaihdon mahdollistamisen lisäksi pohjoismaisia varoja tulee käyttää maiden ja muiden tärkeiden toimijoiden toimintoja koskevan tiedon päivittämiseksi. Lisäksi voidaan käynnistää erityisiä yhteispohjoismaisia aloitteita, esimerkiksi yhteisiä tutkimushankkeita, pilotti- ja demonstraatiohankkeita, valmiuksien kehittämistä, rahoitusinstrumenttien kehittämistä tai viestintää avaintoimijoiden kanssa. Foorumin kautta Pohjoismaat voivat myös osallistua vahvasti Euroopan muovipolitiikan kehittämiseen sekä EU:n muovistrategian täytäntöönpanoon kiertotalouden edistämiseksi.

Ehdotetusta muovialan työstä saatuja kokemuksia voidaan hyödyntää pohjoismaisessa yhteistyössä liittyen muihin materiaalivirtoihin, joissa kiertotaloutta tulee edistää. 
Kemikaalien parissa tehtävän pohjoismaisen ympäristöyhteistyön pitkän aikavälin tavoitteena tulee olla tehokas ja ympäristön kannalta kestävä haitallisten kemikaalien korvaaminen niiltä osin, kun niiden käyttö on riskialtista ympäristön ja ihmisten kannalta. Korvaamisen pohjana tulee olla tieto haitallisten aineiden vaikutuksista ja niitä korvaavista kemikaaleista. Vasta kun kemikaalien vaikutukset ovat tiedossa, voidaan tehdä mahdollisia poliittisia päätöksiä aineiden rajoittamisesta tai korvaamisesta. Siirtyminen kiertotalouteen tekee haitallisten kemikaalien korvaamisesta entistäkin tärkeämpää. Uudelleenkäytettävien materiaalien ongelmalliset aineet tulee korvata myrkyttömän kiertokulun mahdollistamiseksi.

Tietoon perustuva lähestymistapa kemikaalien vaikutuksia arvioitaessa sekä niiden käytössä ja hallinnassa muodostaa EU:n ja Etan kemikaalilainsäädännön pohjan. Sekä kemikaalien rekisteröintiä, arviointia, lupamenettelyjä ja rajoituksia koskevan asetuksen (REACH) että kemikaalien luokitusta, merkintöjä ja pakkaamista koskevan asetuksen (CLP) täytäntöönpanossa kemikaalien käytön mahdollisen sääntelyn tulee perustua arvioon aineiden haitallisista vaikutuksista. Markkinoilla on nykyään yli 100000 kemikaalia. Useista kemikaaleista puuttuu perustavaa laatua olevaa tietoa.

Pohjoismaiden kannalta on hyvin tärkeää, että EU:n kemikaalilainsäädännöstä ja -hallinnosta saadaan mahdollisimman vankka. EU- ja Eta-tason järjestelmän etuna on, että sen avulla ympäristöasioihin saadaan parannuksia maiden rajojen yli. Lisäksi sen myötä luodaan yhtäläisiä toimintaedellytyksiä ja minimoidaan yritysten rajaesteitä. Tämä mahdollistaa tiukemman kemikaalilainsäädännön ilman, että sillä on negatiivisia vaikutuksia maiden kilpailukykyyn.

Erityistä huolta aiheuttavat aineet (SVHC-aineet) ja strategiat niiden korvaamiseksi vähemmän haitallisilla aineilla tai vaihtoehtoisilla tekniikoilla on työnala, jolla pohjoismaisesta ympäristöyhteistyöstä saadaan selvää lisäarvoa. Pohjoismaiden näkemykset ovat olleet ja tulevat olemaan tärkeitä muotoiltaessa kriteereitä, joita käytetään näiden ongelmallisten aineiden määrittämisessä, niiden seulonnassa, aineiden vaikutusten arvioinnissa, niiden riskien minimoinnissa ja sääntelystrategioiden laadinnassa. Pohjoismaita tarvitaan myös REACHtyön tehostamisessa, muun muassa kemikaalien ryhmittelyyn perustuvan arviointimenetelmän kehittämisessä.

Onnistunut seulonta- ja arviointityö edellyttää testausmenetelmien kehittämistä. Testausmenetelmien kehitys vaikuttaa siihen, mitä vaikutuksia voidaan sisällyttää kemikaalien haitallisuutta koskevaan arviointiin. Pohjoismaiden osallistuminen testausmenetelmien kehittämiseen on sen vuoksi tulevaisuudessakin kustannustehokas tapa varmistaa, että aineiden arvioinnissa ja viime kädessä niiden käsittelyssä voidaan ottaa huomioon Pohjoismaita kiinnostavia kysymyksiä. Tällaisia aiheita ovat esimerkiksi hormonitoimintaa häiritseviin aineisiin, nanomateriaaleihin ja mahdollisesti myös vähäisessä määrin maahan tuotaviin tai maassa valmistettaviin aineisiin liittyvät kysymykset. Kemikaalialalla tällaisen vahvaa osaamista edellyttävän esityön poliittinen painoarvo on suuri. Tärkeänä yhteistyökumppanina tähän liittyen ovat OECD ja sen testiohjeita koskeva ohjelma.

Aloilla, joilla on riittävän vahva tietopohja haitallisten kemikaalien korvaamisesta, on ajankohtaista alkaa selvittää, miten haitallisten aineiden korvaamista voidaan edistää yrityksissä. Pohjoismaiden tulee selvittää aktiivisesti mahdollisuuksia organisoida aineiden korvaamista koskevaa tiedonvälitystä kustannustehokkaasti joko pohjoismaisella tasolla tai suhteessa EU:hun, esimerkiksi EU:n kemikaaliviraston (ECHA) kautta. 


\section{SUOSITUS 5}

\section{VAHVISTETAAN YMPÄRISTÖMYÖTÄISEEN TALOUTEEN JA YHTEISKUNTARAKENTEISIIN SIIRTYMISEN ETUJEN TUNTEMUSTA}

Pohjoismaat tunnetaan ympäristömyötäisten ratkaisujen kehittämisen ja täytäntöönpanon edelläkävijämaina. Tulevaisuuden haasteiden osalta on tärkeää, että kaikki toimijat edistävät ympäristön ja ilmaston kannalta kestäviä ratkaisuja. Avaintoimijoiden mobilisoimiseksi pohjoismaisen ympäristö- ja ilmastosektorin tulee auttaa tuottamalla ja levittämällä tietoa ympäristömyötäisiin talous- ja yhteiskuntarakenteisiin siirtymisen merkityksestä taloudelle, terveydelle ja elämänlaadulle. Pohjoismaisen ympäristö- ja ilmastosektorin tulee pyrkiä kuvaamaan vihreään talouteen ja ympäristömyötäisiin yhteiskuntarakenteisiin siirtymistä niin yhteiskunnallisesta kuin taloudellisesta näkökulmasta ymmärrettävällä kielellä.

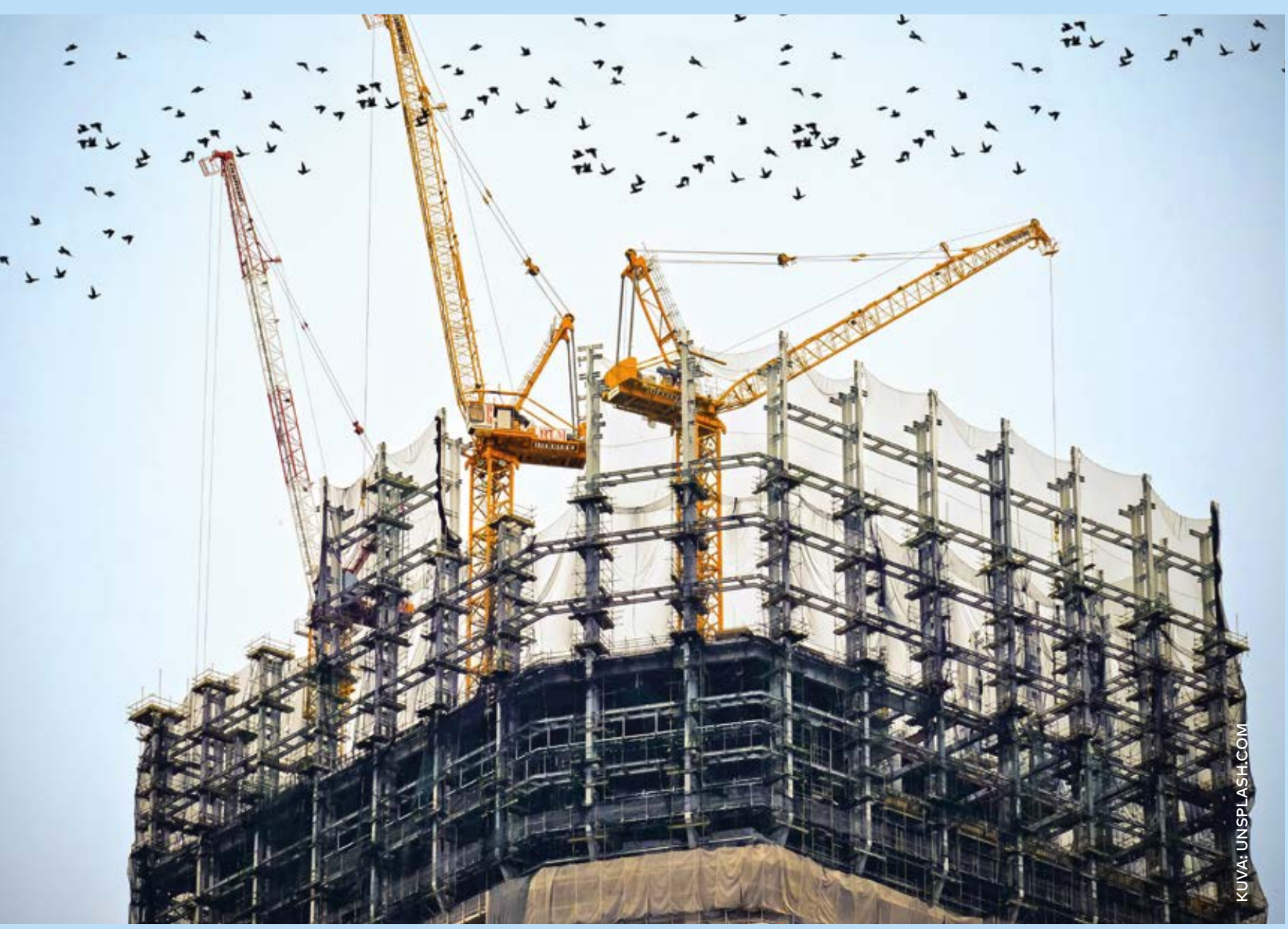


Vihreään talouteen ja ympäristömyötäisiin yhteiskuntarakenteisiin siirtymistä sekä luonnon ja ympäristön hyvää tilaa edistävät päätökset tehdään usein pohjoismaisen ympäristö- ja ilmastosektorin ulkopuolella. Vaikka ympäristötietoisuus kasvaa, on edelleen tarvetta edistää ymmärrystä niistä taloudellisista ja yhteiskunnallisista eduista, jotka liittyvät ympäristömyötäiseen talouteen- ja yhteiskuntarakenteisiin siirtymiseen. Mitä selvemmin tämä toteutetaan, sitä paremmin voimme saada muut asianomaiset toimijat mukaan työhön.

Pohjoismaisessa ympäristö- ja ilmastoyhteistyössä on jo alettu tuoda esille ympäristökysymysten, talouden ja yhteiskunnan välisiä yhteyksiä. Hyviä esimerkkejä tästä ovat ekosysteemipalveluiden parissa tehtävä työ, bruttokansantuotteen vaihtoehdot ja tiettyjen kemikaalien vaikutuksesta lisääntymisterveyteen laadittavat taloudelliset arvioinnit. Jotta muut sektorit ja toimijat saadaan mobilisoitua, pohjoismaisen ympäristö- ja ilmastosektorin tulee järjestelmällisesti hyödyntää työssään yhteiskuntataloudellisia arviointeja. Arvioinnit voivat esimerkiksi koskea öljyn tai muiden ilmaston ja ympäristön kannalta ongelmallisten raaka-aineiden, haitallisten kemikaalien sekä haavoittuvien maa-alueiden ja ekosysteemien käytön rajoittamista. Tämänkaltaiset yhteiskuntataloudelliset arvioinnit ovat erityisen mielenkiintoisia suhteessa ympäristötoimien hintaan sekä kustannuksiin, joita syntyy, mikäli toimiin ei ryhdytä.

Yhteiskuntataloudelliset seuraukset ovat tärkeitä, mutta eivät suinkaan ainoita asioita, jotka tukevat ja oikeuttavat ympäristömyötäiseen talouteen ja yhteiskuntarakenteisiin siirtymistä. Myös luvut kiertotalouden työpaikkojen määrästä tai luvut ihmisistä, jotka eivät voi saada lasta hormonitoimintaa häiritsevien aineiden takia, voivat olla yhtä herättäviä. Interaktiivinen kartta ilmastoon liittyvistä tulevista konflikteista ja pakolaisvirroista voi kuvata ilmastonmuutoksen aiheuttamia sosiaalisia ja poliittisia haasteita. Toisaalta meidän tulee myös levittää hyvää, ilmastoneutraalia elämää koskevaa viestiä.
Niin yhteiskuntatalouden kuin yksilöidenkin saamien etujen lisäksi tulee viestiä myös vihreän talouden ja ympäristömyötäisten yhteiskuntarakenteiden tuomista kilpailueduista. Tarvitsemme liiketoimintasuunnitelman ympäristömyötäiseen talouteen ja yhteiskuntarakenteisiin siirtymisestä politiikan avainalojen parissa toimivien elinkeinoelämän edustajien, poliitikkojen ja viranomaisten kiinnostuksen tueksi. 


\section{SUOSITUS 6}

\section{EDISTETÄÄN YHTEISTYÖTÄ POHJOISMAISTEN YMPÄRISTÖMYÖTÄISTEN RATKAISUJEN VIENNIN EDISTÄMISEKSI}

Pohjoismailla on yhdessä useita teknologioita ja muita ratkaisuja, joita maailma tarvitsee siirtyäkseen vihreään talouteen ja ympäristömyötäisiin yhteiskuntarakenteisiin. Meillä on pitkälle kehitettyjä ratkaisuja esimerkiksi veden, jätteiden, ympäristömyötäisen kaupunkikehityksen, liikenteen ja energian alalla. Pohjoismaiden osaaminen ja ratkaisut täydentävät usein toisiaan. Pohjoismaisen ympäristö- ja ilmastoyhteistyön tulee edistää orastavaa pohjoismaista yhteistyötä ympäristömyötäisten ratkaisujen viennissä. 
State of the Nordic Region 2018 -raportin mukaan Pohjola on Euroopan innovatiivisin alue etenkin puhtaiden teknologioiden osalta. Yhteen laskettuna Pohjoismailla on jo useita ratkaisuja, jotka ovat tarpeellisia Pariisin ilmastosopimuksen sekä kestävän kehityksen ympäristö- ja ilmastotavoitteiden saavuttamiseksi. Mailla on pitkälle kehitettyjä ratkaisuja esimerkiksi veden, jätteiden, ympäristömyötäisen kaupunkikehityksen, liikenteen ja energian alalla. Pohjoismaisen yhteistyön avulla näistä ratkaisuista voitaisiin saada entistä enemmän lisäarvoa globaaleilla markkinoilla.

Kestävien teknologioiden ja muiden ratkaisujen globaalit markkinat kasvavat nopeasti, ja niillä on tilaa kaikkien Pohjoismaiden tuotteille ja palveluille. Ongelma on lähinnä päinvastainen: monet pohjoismaiset yritykset kokevat jo nyt, että kansalliset yritysklusterit ovat liian pieniä hyödyntämään globaalia markkinapotentiaalia. Monilla aloilla Pohjoismaiden osaaminen ja ratkaisut täydentävät lisäksi toisiaan. Tästä johtuen voimme pikemminkin tehdä yhteistyötä kuin kilpailla keskenämme globaaleilla markkinoilla. Pohjoismailla on erittäin suuria mahdollisuuksia solmia kumppanuuksia ympäristömyötäisten ratkaisujen markkinoiden luomiseksi maailman suurimpien markkinoiden, kuten Kiinan, Intian ja Pohjois-Amerikan kanssa.

Pohjoismainen yhteistyö ympäristömyötäisten ratkaisujen vientiin liittyvän lisäarvon luomiseksi on vastikään alkanut. Pohjoismaissa vuonna 2017 lanseeratun pääministerialoitteen Pohjoismaisia ratkaisuja globaaleihin haasteisiin päätavoitteena on edistää pohjoismaisten yritysten laatimien ratkaisujen brändäystä. Sen työaloihin sisältyvät muun muassa kestäviin kaupunkeihin liittyvät pohjoismaiset ratkaisut. Pohjoismaisiin kestävän kehityksen kaupunkeihin liittyvän brändäyksen lisäksi tuetaan myös pohjoismaisten yritysten yhteenliittymiä sekä niiden pyrkimyksiä muodostaa kumppanuuksia mahdollisten kansainvälisten ostajien kanssa. Näistä toiminnoista vastaa Nordic Innovation (NI), kestävän kasvun ministerineuvoston (MR-TILLVÄXT) alainen laitos, tiiviissä yhteydessä kansallisten vientineuvostojen ja suurlähetystöjen kanssa. Pohjoismaisia energiaratkaisuja -hankkeessa esitellään lisäksi alan ratkaisuja ja yrityksiä, jotka keskittyvät Itä-Afrikan sähkömarkkinoihin Pohjoismaisen energiatutkimuksen (NEF) johdolla.

Ympäristömyötäisiin ratkaisuihin tähtäävien kansallisten toimien rahoittaminen voi edistää elinkeinoelämää ja parantaa yritysten kokonaistulosta. Tämä lisää maiden kunnianhimoisen ympäristö- ja ilmastopolitiikan oikeutusta. Sen vuoksi orastavan ympäristömyötäisen vientiyhteistyön edistäminen on kiinnostavaa myös Pohjoismaiden ympäristö- ja ilmastoministerien näkökulmasta. Ehdotuksena onkin, että ympäristö- ja ilmastoministerit seuraavat vientiyhteistyöstä saatuja kokemuksia yhdessä elinkeinoministerien kanssa. Käynnissä olevista ja suunnitelluista toiminnoista saatujen kokemusten pohjalta kyseiset ministerineuvostot voivat selvittää kestäviin kaupunkeihin liittyvien pohjoismaisten lisätoimien tarvetta. Nämä voivat mahdollisesti liittyä jonkin tietyn vientiklusterin, kuten vesihuoltoteknologioiden ja -järjestelmien sekä jäteteknologioiden tai uudenlaisten vienninedistämistoimien kehittämiseen.

Pohjoismaisen ympäristö- ja ilmastosektorin tulee myös edistää muiden potentiaalisten aihealveiden tunnistamista ympäristömyötäisen vientiyhteistyön puitteissa. Myös näitä aihealueita voidaan myöhemmin brändätä vastaavalla tavalla pohjoismaisin voimin ja niiden ympärille voidaan rakentaa vientiklustereita esimerkiksi osana jotakin muuta kokonaisuutta. Muun muassa luonnonvarojen kestävän hallinnoinnin, ilmastonmuutokseen sopeutumisen tai kiertotalouden alalla voidaan mahdollisesti kehittää vahvoja pohjoismaisia vientiartikkeleita. Pohjoismainen projektivientirahasto (Nopef) ja kansalliset vientiluotto-organisaatiot voivat myös olla tärkeitä toimijoita pohjoismaisten ympäristömyötäisten ratkaisujen vientiyhteistyössä. 


\title{
SUOSITUS 7
}

\author{
TUETAAN JA VAHVISTETAAN POHJOISMAISTA \\ JOUTSEN-YMPÄRISTÖMERKKIÄ
}

Pohjoismainen ympäristö- ja ilmastoyhteistyö tavoittaa kuluttajat parhaiten pohjoismaisen Joutsen-ympäristömerkin avulla. Ostamalla Joutsenmerkittyjä tuotteita kuluttaja voi vaikuttaa kulutuksensa ympäristöseurauksiin. Sen vuoksi pohjoismaisen ympäristöyhteistyön tulee jatkaa Joutsenmerkin tukemista ja vahvistamista. Tämä voi tapahtua monella eri tavalla. Sen lisäksi, että sektori tukee suoraan Joutsenmerkki-organisaation työtä, myös julkiset hankinnat ja myönteisten hintakannustimien kehittäminen ympäristömerkityille tuotteille voivat tarjota hyviä mahdollisuuksia Joutsenmerkin vahvistamiseen.

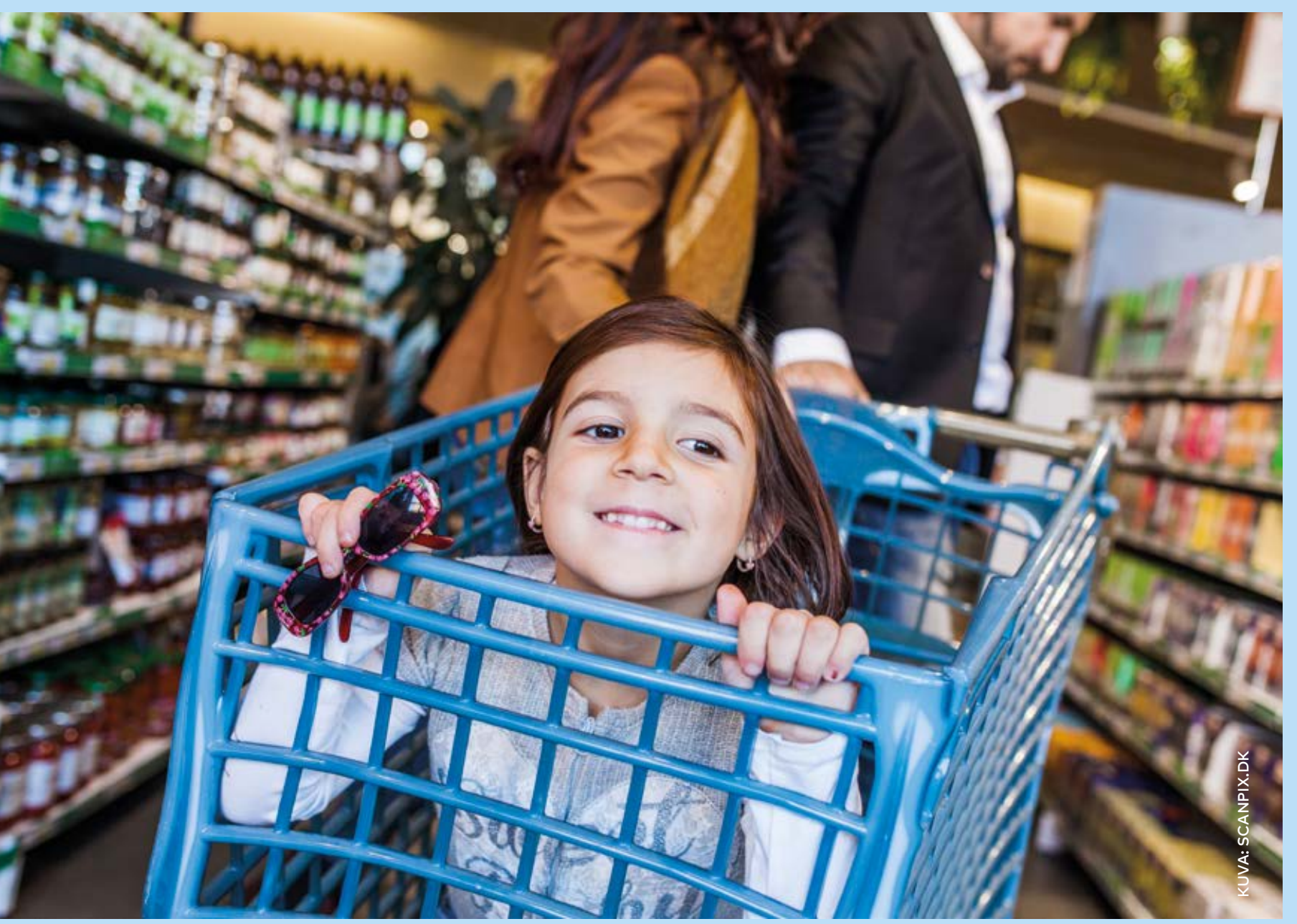


Pohjoismaiden ministerineuvosto perusti Joutsenmerkin, virallisen pohjoismaisen ympäristömerkin, vuonna 1989. Se on parhaiten tunnettu ympäristömerkki Pohjoismaissa, ja jopa 89 prosenttia väestöstä tuntee Joutsenlogon. Joutsenmerkki on tärkeä väline kuluttajien tietämyksen vahvistamisessa ja lisäämisessä: sen avulla he voivat tehdä luotettavia ja ympäristötietoisia valintoja ilman asiantuntijaosaamista.

Pohjoismaisen ympäristö- ja ilmastoyhteistyön tulee jatkossakin osallistua aktiivisesti Joutsenmerkin tukemiseen ja vahvistamiseen, jotta merkin asema olisi entistäkin vahvempi kestävän kulutuksen edistämisessä. Se voi tapahtua monin eri tavoin ja monella eri tasolla. Pohjoismaisen ympäristö- ja ilmastosektorin tulee ensinnäkin jatkaa Joutsenmerkin strategisen kehittämisen tukemista yhteistyössä pohjoismaisen Joutsenmerkkiorganisaation kanssa. Tavoitteena on, että entistä useammat ostavat Joutsenmerkittyjä tuotteita, että markkinoilla on enemmän Joutsenmerkittyjä tuotteita ja että niitä on entistä useammassa tuoteryhmässä. Lisäksi Joutsenmerkin kokonaisvaltainen digitalisaatio on välttämätöntä, jotta merkki saadaan päivitettyä digiaikaan.

Toiseksi pohjoismainen ympäristö- ja ilmastoyhteistyö voi vahvistaa Joutsenmerkkiä edistämällä ympäristömerkkien käyttöä julkisissa hankinnoissa. Vuonna 2017 julkistettiin pohjoismaiset suuntaviivat vuonna 2014 annetun julkisia hankintoja koskevan EU-direktiivin tulkinnasta erityisesti ympäristömerkkien käytöstä EU-hankinnoissa. Nämä suuntaviivat muodostavat yhdessä useiden muiden ympäristömyötäisiä hankintoja koskevien pohjoismaisten hankkeiden kanssa hyvän pohjan jatkotyölle, joka koskee ympäristömerkkien, mukaan lukien Joutsenmerkin, käytön edistämistä julkisissa hankinnoissa.

Kolmanneksi pohjoismainen ympäristö- ja ilmastoyhteistyö voi edistää Joutsenmerkkiä selvittämällä mahdollisuuksia luoda positiivisia hintakannustimia ympäristömerkityille tuotteille. Ympäristöä säästävän kuluttamisen tulee olla helppoa, yksinkertaista ja taloudellisesti kannattavaa, jotta kuluttajien muutoshalusta voidaan saada todellisia tuloksia. Tästä huolimatta tuotteen ympäristömerkkiin liittyvät kustannukset maksaa nykyään lisenssin omistaja - ja viime kädessä kuluttaja.

Pohjoismaiden ministerineuvostossa ei ole kuluttaja-asioita käsittelevää ministerineuvostoa tai työryhmää, eivätkä kuluttajaviranomaiset osallistu - muutamaa poikkeusta lukuun ottamatta - pohjoismaiseen ympäristö- ja ilmastoyhteistyöhön. Tässä tilanteessa pohjoismaisen ympäristö- ja ilmastosektorin on priorisoitava varojensa käyttöä kuluttajien tavoittamiseen tähtäävissä toimissaan. Ministerineuvoston näkökulmasta Joutsenmerkki on todennäköisesti tehokkain ja toimivin keino tulosten saavuttamiseksi tällä alalla. Ympäristömerkintä on myös osa elinkeinoelämän panostusta ympäristöön ja ilmastoon. Sen vuoksi ministerineuvoston elinkeinosektori on ilmeinen yhteistyökumppani Joutsenmerkin parissa tehtävässä työssä. 


\section{SUOSITUS 8}

\section{TUETAAN MAITA JULKISTEN VAROJEN KÄYTÖN OPTIMOINNISSA YMPÄRISTÖMYÖTÄISEEN TALOUTEEN JA YHTEISKUNTARAKENTEISIIN SIIRTYMISEN EDISTÄMISEKSI}

Siirtyminen vähäpäästöiseen yhteiskuntaan edellyttää lisärahoitusta ympäristöä ja ilmastoa säästäviin innovaatioihin. Julkisesti rahoitetut tukijärjestelmät, julkiset hankinnat ja julkisen rahoituksen käyttö suurissa infrastruktuurihankkeissa muodostavat yhdessä varojen virran, jossa on paljon potentiaalia edistää ympäristömyötäisten ratkaisujen kehitystä, kaupallistamista ja täytäntöönpanoa. Pohjoismaisen ympäristö- ja ilmastoyhteistyön tulee edistää Pohjoismaiden välistä kokemustenvaihtoa ja tiedon lisäämistä siitä, miten näillä instrumenteilla voidaan parhaiten edistää siirtymistä vihreään talouteen ja ympäristömyötäisiin yhteiskuntarakenteisiin.

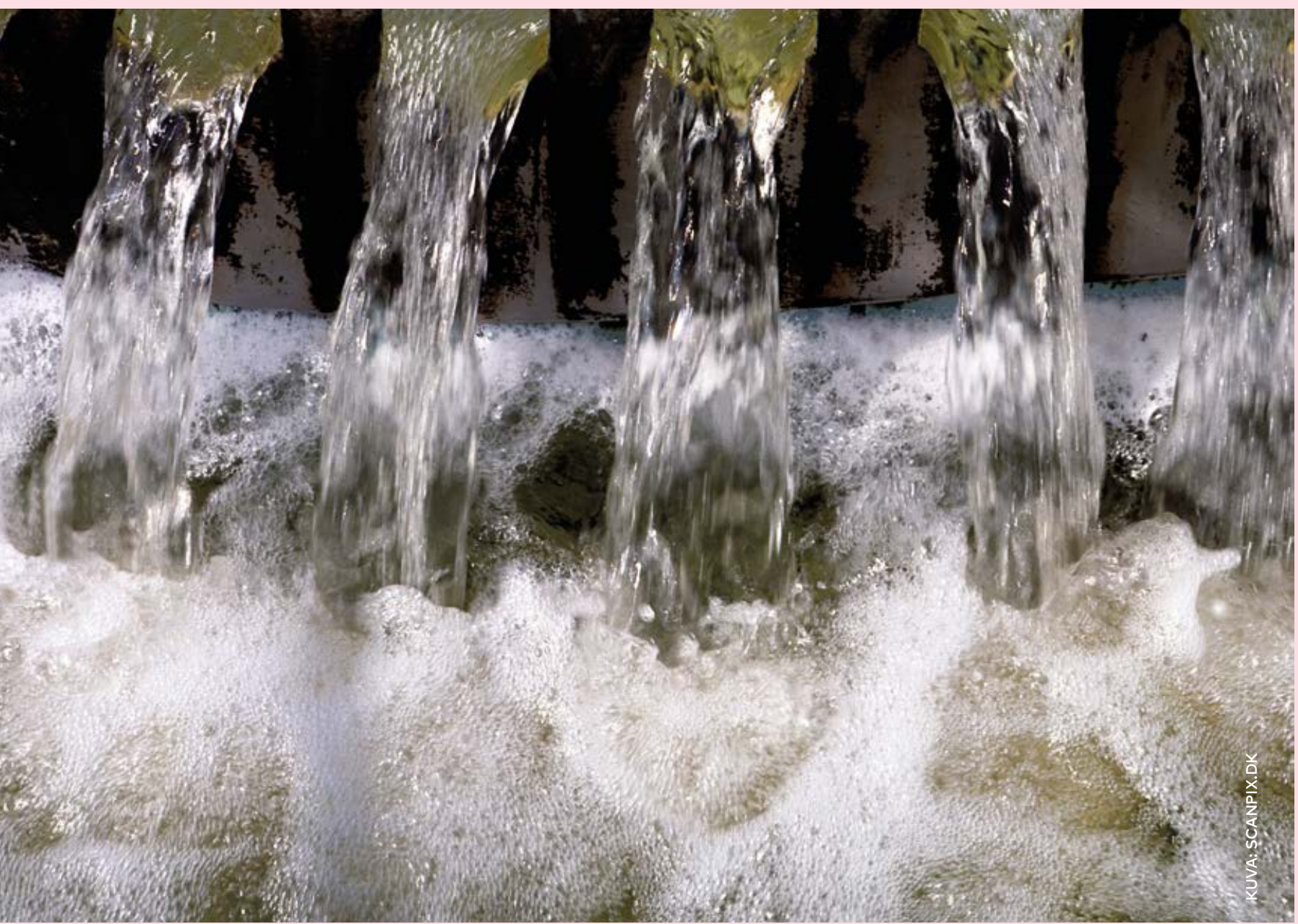


Arvion mukaan pelkästään EU-alveella ympäristömyötäisiin ratkaisuihin tarvitaan vuosittain 170 miljardia euroa lisävaroja Pariisin ilmastosopimuksen tavoitteiden saavuttamiseksi vuoteen 2030 mennessä. Agenda 2030:n ympäristötavoitteiden täyttämiseen tarvitaan vieläkin suurempaa rahoituspanostusta. Varoja tarvitaan suurten järjestelmä- ja infrastruktuurimuutosten kehittämiseen, kaupallistamiseen ja täytäntöönpanoon sekä pienempiin innovaatioihin käytännössä katsoen kaikilla talouden aloilla. Tulevina vuosina on erityisen tärkeää vauhdittaa lupaavien ja jo testattujen vähäpäöstöiseen yhteiskuntaan tähtäävien ratkaisujen kaupallistamista.

Pohjoismaiden julkisissa tukijärjestelmissä, kuten ympäristöinnovaatioille sekä muille innovaatioille myönnettävissä lainoissa, tuissa ja takuissa, on eroja. Maissa on rahastoja ja ohjelmia, joista sekä julkiset että yksityiset toimijat voivat hakea tukea. Rahoitusta myönnetään tavallisesti kehitykseen, testaukseen ja demonstraatioihin. Joillakin rahoitusinstrumenteilla tuetaan myös markkinakehitystä tukevia jatkotoimia. Tämäntyyppisellä julkisella tuella on olennainen merkitys uusien innovaatioiden kehittämisessä ja levittämisessä. Lisäksi julkinen taloudellinen tuki voi auttaa houkuttelemaan yksityistä pääomaa riskialttiimpiin innovaatio- ja kaupallistamishankkeisiin.

Konkreettisella tasolla suositellaan käynnistettäväksi pohjoismaista kokemustenvaihtoa ja tiedon kokoamista julkisen taloudellisen tuen instrumenteista. Kokemustenvaihdon tavoitteena on lisätä maiden ymmärrystä siitä, miten näitä instrumentteja voidaan hyödyntää parhaiten vihreään talouteen ja ympäristömyötäisiin yhteiskuntarakenteisiin siirtymisessä. Tässä yhteydessä voi myös olla hedelmällistä keskustella, voidaanko tukivarojen lisäpalveluilla, kuten neuvonnalla ja sparrauksella, lisätä tuen vaikutusta. Lisäksi on tärkeää pohtia eri järjestelmien yhteisvaikutuksia ja arvioida mahdollista tarvetta tehdä muista nykyisistä tukijärjestelmistä ympäristömyötäisempiä. Tämän tiedon pohjalta taloudellisen tuen kansallisia mekanismeja ja järjestelmiä voidaan optimoida vihreään talouteen ja ympäristömyötäisempiin yhteiskuntarakenteisiin siirtymisen edistämiseksi.

Edellä mainittujen tukijärjestelmien lisäksi on myös muita keinoja käyttää julkisia varoja ympäristöinnovaatioiden ja -ratkaisujen edistämiseksi. Julkisten hankintojen ja investointien parissa on paljon mahdollisuuksia kasvattaa ympäristöä säästävien tuotteiden, palveluiden ja muiden järjestelmätason ratkaisujen kysyntää. Sen vuoksi suositellaan tiedon- ja kokemustenvaihtoa siitä, miten eri Pohjoismaissa on kohdennettu julkisia varoja vihreään talouteen ja ympäristömyötäisempiin yhteiskuntarakenteisiin siirtymisen tukemiseen julkisten hankintojen ja investointien avulla. 
Pariisin ilmastosopimuksen tavoitteiden ja Agenda 2030 -toimintaohjelman ympäristö- ja ilmastotavoitteiden täyttäminen edellyttää perustavaa muutosta taloudellisten resurssien käytössä. Ympäristöä ja ilmastoa säästävään infrastruktuuriin suunnatut julkiset tukivarat, hankinnat ja toimenpiteet ovat ensimmäinen askel muutoksessa (suositus 8). On kuitenkin ilmiselvää, etteivät ne yksin riitä: tavoitteen saavuttamiseen tarvitaan sekä yksityistä että yhteisösijoittajien pääomaa.

Euroopan komission kestävää rahoitusta käsittelevä korkean tason asiantuntijaryhmä (HLEG) on vastikään julkaissut suosituksensa siitä, miten EU-tasolla voitaisiin saada aikaiseksi ympäristömyötäisempi rahoitusjärjestelmä. Ryhmän keskeisiin päätelmiin kuuluu se, että muutoksia on tehtävä rahoitusmaailman monilla eri aloilla. HLEG painottaa etenkin ympäristömyötäisten investointien ja investointituotteiden yhteisten määritelmien ja standardien kehittämisen tarvetta, avoimia ja vertailukelpoisia tietoja ympäristömyötäisistä investointimahdollisuuksista sekä ympäristöön ja ilmastoon liittyvistä riskeistä. Lisäksi suosituksissa korostetaan mahdollisuuksia sisällyttää kestävyysnäkökulmia sekä rahoituslaitosten että rahoitusvalvonnan työhön. Ryhmä ehdottaa myös muun muassa pankkeihin sekä vakuutus-, varainhoito- ja pörssiyhtiöihin kohdistuvia toimia.

HLEG:n suosituksista käy selvästi ilmi, että nyt tarvitaan sekä politiikan toimia että yksityisten rahoituslaitosten ja -järjestöjen kanssa tehtävää yhteistyötä. EU:n kestävän rahoituksen toimintasuunnitelma, joka on tarkoitus julkaista maaliskuussa 2018, näyttää EU-tason työn suunnan. Työtä tulee tukea ja täydentää sekä alveellisilla että kansallisilla toimilla. Sen vuoksi suositellaan, että Pohjoismaiden ympäristö- ja ilmastoministerit käynnistävät vuoropuhelun valtiovarainministerien sekä rahoitusalan avaintoimijoiden, kuten suurten yhteisösijoittajien, rahoitusalan ammattijärjestöjen ja Pohjoismaiden Investointipankin, kanssa tavoitteena määrittää ja selvittää pohjoismaisten toimien mahdollisuuksia. Nämä pohdinnat ovat tärkeitä myös kansallisen kehityksen tukemisessa ja kannustamisessa. Konkreettisesti pohdintoja voidaan toteuttaa virallisena pohjoismaisena huippukokouksena tai korkean tason avoimena kartoittavana vuoropuheluna. 


\section{SUOSITUS 10}

\section{KEHITETÄÄN KANSAINVÄLISILLÄ FOORUMEILLA TEHTÄVÄÄ POHJOISMAISTA YHTEISTYÖTÄ KOSKEVA SUUNNITELMA}

Tulevat kolme vuotta ovat ratkaisevia ilmasto-, monimuotoisuus- ja kemikaalialaa koskevien kansainvälisten ympäristöpoliittisten neuvotteluprosessien kannalta. Pohjoismaiden ympäristö- ja ilmastoministerien tulee laatia suunnitelma siitä, missä kohdin näitä prosesseja tulee ryhtyä strategisiin pohjoismaisiin aloitteisiin. Suunnitelman toteuttamiseksi varataan rahoitusta tiedon lisäämiseen, tiedon ja parhaiden käytäntöjen levittämiseen sekä yhteisiin neuvottelupanostuksiin niin virallisessa kuin epävirallisessakin pohjoismaisessa ympäristö- ja ilmastoyhteistyössä.

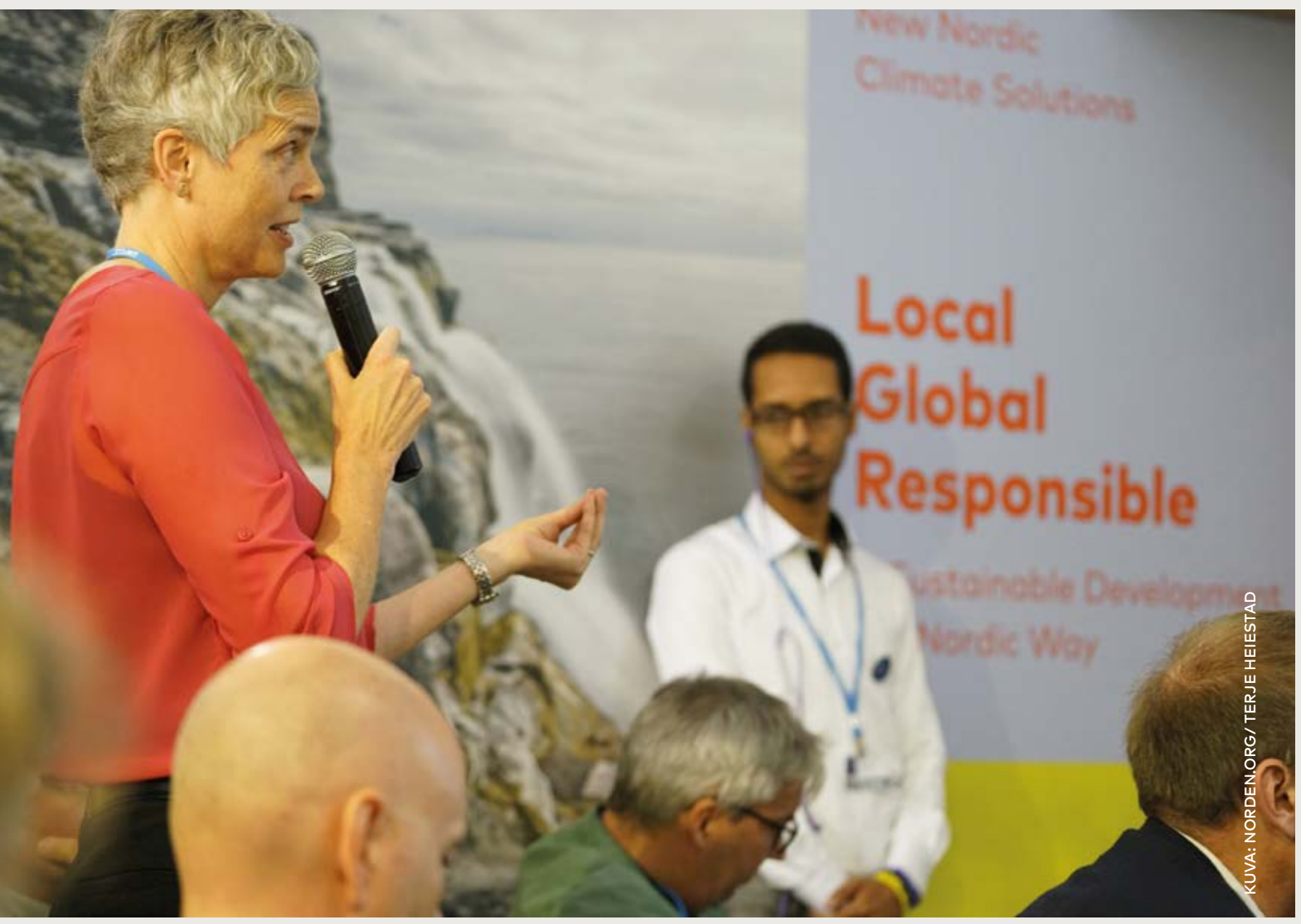


Pohjoismaita arvostetaan suuresti maailmalla. Arvostus pohjautuu Pohjoismaiden vakaaseen ympäristö- ja ilmastotyöhön. Lisäksi Pohjoismailla on aktiivinen vuoropuheluun ja tietoon pohjautuva asema kansainvälisissä yhteyksissä. Se tarkoittaa, että Pohjoismailla on kaikkiaan enemmän pehmeää poliittista valtaa kuin pelkän väestömäärän pohjalta voisi ajatella.

Myös pohjoismaisen yhteistyön parissa on rakennettu Pohjoismaiden hyvää kuvaa ja uskottavuutta kansainvälisesti. Pohjoismaisia varoja on käytetty ympäristöä ja ilmastoa koskevan tiedon tuottamiseen. Neuvotteluissa Pohjoismaat ovat edistäneet joidenkin aihealveiden käsittelyä yhteisillä julkilausumilla ja tukemalla toistensa ehdotuksia. Ilmastoneuvottelujen yhteydessä Pohjoismaiden edustajat ovat tehneet onnistunutta yhteistyötä ilmastoneuvottelujen pohjoismaisessa työryhmässä (NOAK). Virallisen pohjoismaisen ympäristö- ja ilmastoyhteistyön ulkopuolisten pohjoismaisten neuvottelijoiden muodostamat epäviralliset verkostot ovat myös todiste pohjoismaisen yhteistyön voimasta.

Tulevina vuosina käydään tärkeitä ilmastoon, kemikaaleihin ja luonnon monimuotoisuuteen liittyviä kansainvälisiä neuvotteluja. Maailmanlaajuisesti jatkuvasti lisääntyvät hiilidioksidipäästöt eivät tee Pariisin ilmastosopimuksen tavoitteiden toteutumisesta helppoa. Kansainvälinen kemikaalistrategia (SAICM) on voimassa vuoteen 2020 asti, ja keskustelu kansainvälisen kemikaali- ja jäteyhteistyön mahdollisesta tulevasta toiminta-alustasta on alkanut. Luonnon monimuotoisuuteen liittyvissä kysymyksissä on alettu valmistella prosessia vuoden 2020 jälkeisen uuden toimintakehyksen laatimiseksi YK:n johdolla.

Pohjoismaat voivat päästä pidemmälle tekemällä yhteistyötä kansainvälisillä foorumeilla. Vaikka kansainvälisten neuvotteluiden kehityskulkuja on tyypillisesti vaikea ennustaa, neuvotteluille ovat myös tunnusomaisia pitkään kestävät strategiset keskustelut tunnetuista ongelmakohdista. Sen vuoksi Pohjoismaiden ympäristö- ja ilmastoministerien tulee laatia suunnitelma siitä, miten pohjoismaisia aloitteita käytetään näissä prosesseissa maiden yhteisten tulevaisuuden tavoitteiden saavuttamiseksi. Tavoitteena tulee olla strateginen ja elävä työkalu, jonka avulla voidaan järjestelmällisesti hyödyntää tiedontuotantoa sekä levittää tietoa ja parhaita käytäntöjä tulevissa neuvotteluissa. Suunnitelma tulee laatia yhdessä niin sektorin virallisten pohjoismaisten työryhmien kuin epävirallisten pohjoismaisten verkostojen kanssa. Tällä tavalla voidaan optimoida ministeritason yhteistyön kautta saatavien varojen ja muiden keinojen käyttöä. 


\section{SUOSITUS 11}

\section{LAADITAAN POHJOISMAINEN TOIMINTASUUNNITELMA EKOSYSTEEMIEN ILMASTOKESTÄVYYDESTÄ JA LUONNON MONIMUOTOISUUDESTA}

Ilmastonmuutos lisää ekosysteemeihimme ja niiden peruskiveen, lvonnon monimuotoisuuteen, kohdistuvaa painetta. Se voi vaikeuttaa ekosysteemien tarjoamien palveluiden, kuten ruoan, puhtaan ilman ja veden saatavuutta. Ekosysteemien ilmastokestävyys on sen vuoksi ratkaiseva tekijä elämänlaatumme ja taloutemme kannalta nyt ja tulevaisuudessa. Maiden tulee laatia pohjoismainen toimintasuunnitelma luonnon ilmastokestävyyden parantamista koskevan tiedon ja kapasiteetin lisäämisestä. Pohjoismaista yhteistyötä tarvitaan myös, jotta eläinten ja kasvien mahdollisuudet sopeutua uusiin ilmasto-oloihin saadaan turvattua yli maiden rajojen.

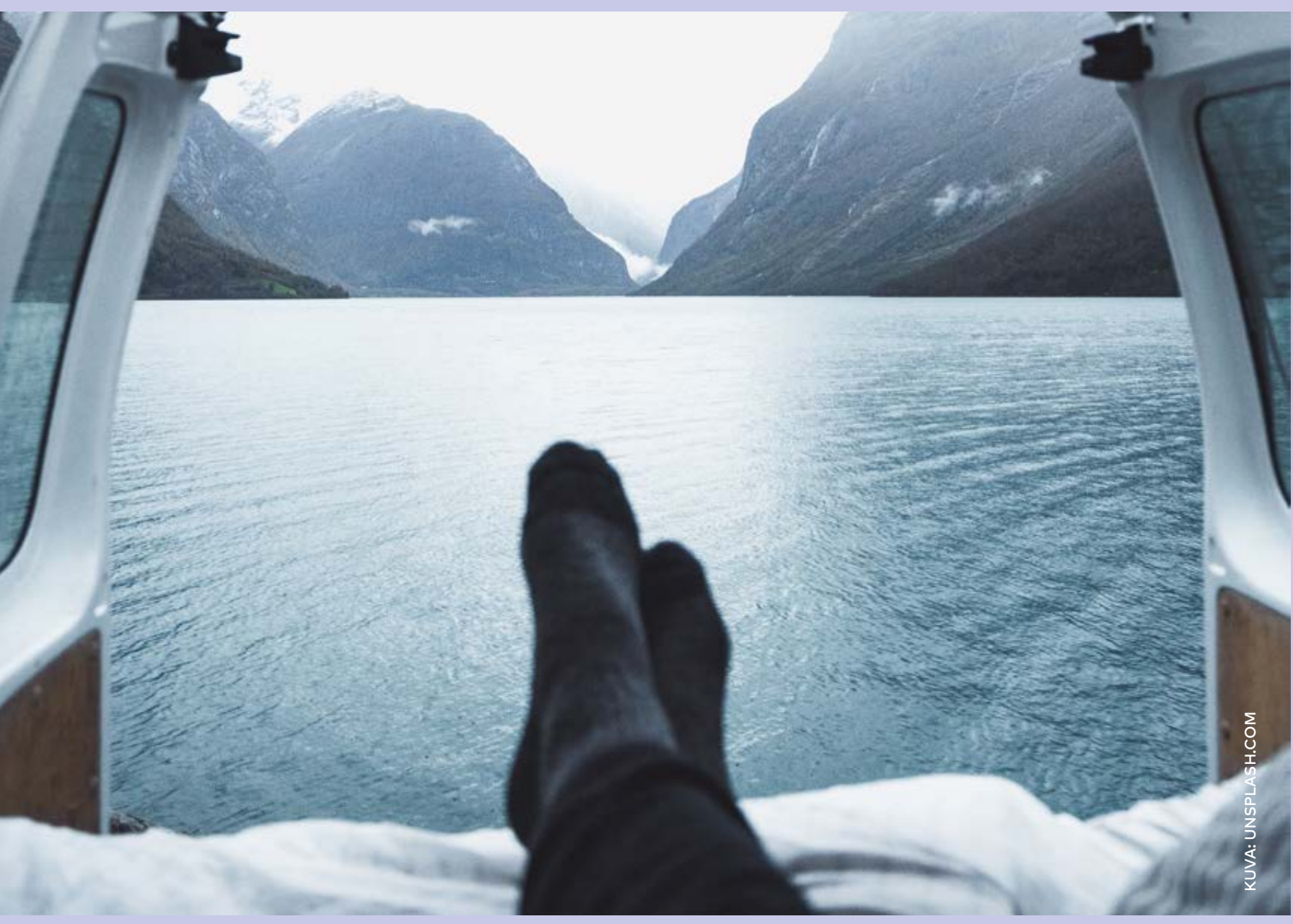


Olemme erittäin riippuvaisia ekosysteemipalveluista, kuten puhtaasta vedestä ja ilmasta, ruoasta, pölytyksestä ja ilmaston säätelystä. Tästä huolimatta ihmisten ja talouden toiminta, kuten maa- ja metsätalous, kalastus, kaupunkikehitys ja infrastruktuurilaajennukset, aiheuttavat suuria paineita ekosysteemeille ja niiden kestokyvylle. Ekosysteemit sirpaloituvat ja tuhoutuvat, minkä seurauksena erilaisten lajien elinehdot heikentyvät ja luonnon monimuotoisuus häviää. Koska luonnon monimuotoisuus on ratkaiseva tekijä ekosysteemien palvelukyvyn ja muutoskestävyyden kannalta, luonnon monimuotoisuuden kato heikentää myös näitä.

Ilmastonmuutos lisää entisestään ekosysteemeihimme kohdistuvaa painetta. Lämpötilan nousu ja ilmastonmuutos etenevät tulevaisuudessa niin nopeasti, etteivät kaikki lajit ehdi sopeutua niihin tai siirtyä muille levinneisyysalueille. Sen myötä lajien riski heikentyä tai hävitä kasvaa merkittävästi. Luonnon monimuotoisuuden kato vaikuttaa eri ekosysteemien kykyyn tuottaa ekosysteemipalveluja. Kun koko luonnon monimuotoisuus vähenee, myös ekosysteemien toimintakyky heikkenee.

Terveet ja vahvat ekosysteemit kestävät paremmin ilmastonmuutoksen vaikutuksia. Muutoskykyisten ekosysteemien on myös helpompi toipua sekä sopeutua muuttuneisiin elinoloihin. Muutoskyvyn lisäämisen ja säilyttämisen paras strategia on huolehtia riittävän laajoista lajistoista ja tarvittavien elinympäristöjen määrästä. Tämä toteutetaan sekä vahvistamalla jo heikentyneitä ekosysteemejä että minimoimalla muiden stressitekijöiden aiheuttamaa terveisiin ja vahvoihin ekosysteemeihin kohdistuvaa painetta. Tämän lisäksi on tärkeää taata elinympäristöjen välisiä väyliä, jotta eläinten luonnollinen muutto paikasta toiseen onnistuu vihreiden ja sinisten ekologisten käytävien kautta.
Ilmastonmuutokseen liittyvä sopeutumistyö on aloitettu kaikissa Pohjoismaissa. Pohjoismaat ovat myös käynnistäneet tutkimusaloitteita tavoitteena selvittää, mihin luontotyyppeihin ja ekosysteemeihin ilmastonmuutos vaikuttaa eniten. Samaan aikaan maat laativat pohjoismaisen yhteistyön puitteissa myös pohjoismaisten ekosysteemien ja ekosysteemipalveluiden tilannekatsausta (Pohjoismainen IBPES-foorumi). Pohjoismaiden on nyt hyvä oppia toinen toisiltaan ja verrata kansallisia toimia, jotka liittyvät esimerkiksi ilmastoasioiden sisällyttämiseen lvonnon hallinnointiin, maankäytön fyysiseen suunnitteluun sekä toimenpiteisiin luonnon palautumis- ja kehittymiskykyyn vaikuttavilla aloilla. Yhteistyössä tulee sen vuoksi käsitellä lainsäädäntöä, politiikan vaikutuskeinoja, tukijärjestelmiä ja paikallisten toimijoiden asemaa ilmastokestävyyden parissa tehtävässä työssä. Konkreettiset menetelmät toimenpiteiden keskinäisen yhteensopivuuden aikaansaamiseksi, toipumiskyvyn lisäämiseksi ja ekosysteemien elpymisen ja dynaamisen kehityksen mahdollistamiseksi ovat niin ikään keskeisiä tekijöitä yhteistyössä, jonka tavoitteena on säilyttää ja parantaa Pohjoismaiden alveen ekosysteemien tilaa. Lisäksi voidaan selvittää Pohjoismaiden luonnon yhteisiä ongelmakohtia, kuten arktisia alveita ja rannikkoalueiden luontoa sekä taata leviämiskäytäviä Pohjoismaissa. Järjestelmällisen pohjoismaisen yhteistyön sekä entistä parempaa ilmastokestävyyttä koskevan tiedon ja kapasiteetin kokoamista koskevan työnjaon avulla Pohjoismaat voivat päästä pitkälle yhteisten varojensa turvin. 


\section{SUOSITUS 12}

\section{KEHITETÄÄN POHJOISMAISTA HYÖTYÄ LISÄÄVÄN POHJOISMAISEN YHTEISTYÖN MUOTOJA}

Pohjoismainen ympäristö- ja ilmastoyhteistyö toimii hyvin ja maat ovat vahvasti sitoutuneita siihen. Yhteistyömuotoja voidaan kuitenkin vielä kehittää, jotta niistä saadaan entistä suurempia vaikutuksia ja etuja maille. Strategisten kärkialoitteiden, maiden välisen paremman työnjaon ja kansallisten varojen sekä työpanosten koordinoinnin avulla maat voivat saada aikaan entistä suurempia myönteisiä ympäristövaikutuksia. Kun yksi maa isännöi tiettyä aloitetta, yhtymäkohta kansalliseen poliittiseen kontekstiin ja asiantuntemukseen vahvistuu.

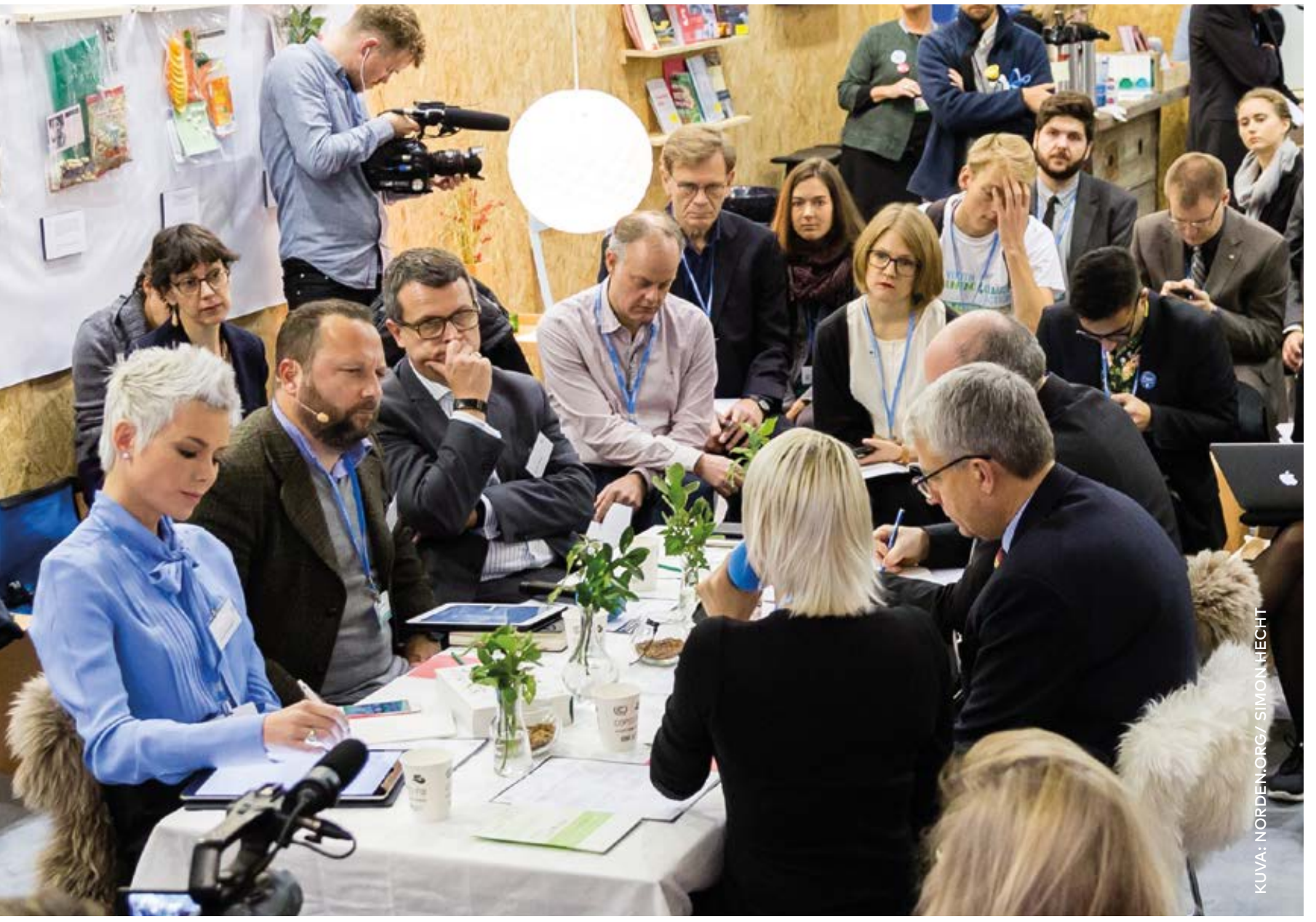


Pohjoismaiseen ympäristö- ja ilmastoyhteistyöhön sisältyy useita erilaisia teemoja, ja Pohjoismaat ovat sitoutuneet siihen vahvasti. Kansallinen jäsenyys sektorin työryhmissä osallistaa laajan pohjoismaisen verkoston ja takaa suoran yhteyden kansallisiin prioriteetteihin. Pohjoismaisen verkoston laajuus painaa samanaikaisesti jälkensä yhteistyöhön siten, että sirpaloitumisen riski kasvaa. Koska työtä tehdään lähes poikkeuksetta kiinteissä työryhmissä, työryhmien osaamisalveiden ulkopuolelle jääviin aiheisiin liittyvät hankkeet ovat niin ikään haasteellisia. Nykyistä pohjoismaista ympäristö- ja ilmastoyhteistyötä voidaan sen vuoksi täydentää kolmella eri työmuodolla, jotka esitellään seuraavaksi.

Ensinnäkin kärkialoitteita ja -hankkeita voidaan käyttää laajemmin pohjoismaisessa ympäristö- ja ilmastoyhteistyössä strategisesti tärkeiden kysymysten edistämiseksi. Priorisoinnin mahdollistamiseksi suositellaan, että maat määrittelevät yhdessä kansallisten huippuvirkamiesten ja viranomaisten edustajien kanssa strategisia aloitteita 2-3-vuotisille ohjelmankaltaisille jaksoille. Se voidaan toteuttaa esimerkiksi kutsumalla asianomaisten kansallisten viranomaisten johtajia vuoropuheluun. Näiden kärkialoitteiden lisäksi on oltava tilaa myös ad hoc -tyyppisille hankkeille sekä työryhmien verkostotyölle.

Toiseksi työryhmärakenne merkitsee rajoitteita esimerkiksi pohjoismaisissa aloitteissa, jotka edellyttävät sellaista osaamista, jota työryhmien jäsenillä ei ole. Tämäntyyppisissä aloitteissa voitaisiin harkita, että kehitysvastuu ja pohjoismainen koordinointivastuu rahoitus mukaan lukien ohjataan yhdelle kansalliselle viranomaiselle. Tämän etuna olisi, että näin saataisiin asianomaisten asiantuntijoiden ja hankkeen johdon välille suora yhteys ja voitaisiin varmistaa isäntälaitoksen koko osaamisvarannon saatavuus. Isäntämaa voitaisiin valita ministerineuvoston puheenjohtajuuden tai kiinnostuksen ja mahdollisuuksien mukaan. Pohjoismaisella ympäristösektorilla on aiemmin käytetty vastaavia työmenetelmiä esimerkiksi muovi- ja tekstiilialan työssä.
Kolmanneksi pohjoismaisen yhteistyön vaikutus voi olla suurempi, mikäli jäsenmaat suhtautuvat pohjoismaiseen rahoitukseen yhteistyön katalysaattorina ja itse pohjoismaiseen yhteistyöhön kansallisten aloitteiden välisen koordinoinnin foorumina. Pohjoismaisessa kemikaaliyhteistyössä on joiltakin osin koordinoitu maiden kansallisia aloitteita suhteessa EU:n kemikaaliarviointeihin. Tuloksena on ollut vahvempi kontribuutio, jolla on ollut enemmän vaikutusta. Joissakin tapauksissa Pohjoismaat täydentävät pohjoismaista rahoitusta kansallisilla varoilla laajempien hankkeiden tai aloitteiden aikaansaamiseksi. Periaatteessa maita yhteisesti kiinnostavia selkeästi rajattuja aihealveita voitaisiinkin edistää myös siten, että kaikkien - tai asiasta kiinnostuneiden - Pohjoismaiden tiettyyn tarkoitukseen varattu kansallinen rahoitus kerättäisiin yhteen tai kansallisten varojen käyttöä koordinoitaisiin. Kansallisen työn sekä kansallisten aloitteiden ja varojen koordinointi on mielekästä erityisesti tiedontuotannon ja viestinnän osalta. 
Pohjoismaiden ministerineuvosto

Nordens Hus

Ved Stranden 18

DK-1061 København K

www.norden.org

\section{POHJOISMAAT VIHREÄSSÄ MURROKSESSA - ENEMMÄN KUIN} NAAPUREITA

Pohjoismaat ovat tehneet usean vuosikymmenen ajan ympäristön- ja luonnonsuojeluyhteistyötä. Tässä raportissa esitellään ulkopuolisen strategiaselvityksen suosituksia, jotka koskevat Pohjoismaiden ympäristö- ja ilmastoasiain ministerineuvoston puitteissa tehtävää virallista pohjoismaista yhteistyötä. Suositukset koskevat viittä aihepiiriä: konkreettisia ratkaisuja vihreään talouteen ja ympäristömyötäisiin yhdyskuntarakenteisiin siirtymiseksi, avaintoimijoiden mobilisointia, vihreään talouteen ja ympäristömyötäisiin yhdyskuntarakenteisiin siirtymisen rahoittamista, kansainvälistä yhteistyötä ja sopeutumista ilmastonmuutokseen.

Raportti kuuluu Pohjoismaiden ministerineuvoston tulevaisuuteen tähtäävien strategiaselvitysten sarjaan. Tähän mennessä strategiaselvityksiä on laadittu työelämä-, terveys- ja energia-alalla. Selvitykset ovat osa ministerineuvoston Nyt Norden -uudistustyötä. 